\title{
DOS EFEITOS DA DAÇÃO EM PAGAMENTO NOS CASOS DE CREDOR EVICTO*
}

\author{
Alessandro Hirata \\ Aluno do Curso de Graduação da Faculdade de Direito da \\ Universidade de São Paulo
}

\begin{abstract}
Resumo:
A análise dos casos de evicção na dação em pagamento apresenta soluções opostas nos diversos ordenamentos estrangeiros e, especialmente, no Código Civil brasileiro. Essa controvérsia é originária das fontes romanas, destacando-se os textos de Marciano e Ulpiano. Por conseguinte, faz-se necessária a abordagem sobre a natureza jurídica da dação em pagamento, já que é fator determinante para o tratamento dos casos de credor evicto.

Desse modo, após esta investigação, explica-se as diversas possibilidades de solução existentes para os casos de credor evicto. Finalmente, o autor desse artigo procura apontar a melhor solução para o tratamento dessa matéria.
\end{abstract}

\begin{abstract}
:
The analysis of the cases of eviction in the datio in solutum shows different solutions in many systems of law, especially in the Brazilian Civil Code. This problem is founded on Roman Law, particularly on texts of Marcianus and Ulpianus. Due to that circumstance, it's necessary to examine the nature of the datio in solutum, because the treatment of the cases of eviction is based on it. Then, after this investigation, the possibilities of the cases of evicted creditor are explained. Finally, the author of the present essay tries to demonstrate which is the best solution to the treatment of this subject.
\end{abstract}

Unitermos: dação em pagamento; extinção das obrigações; eviç̧ão.

* O presente artigo é parte do relatório final, apresentado como resultado da pesquisa realizada pelo Autor como bolsista do PIBIC/CNPq, durante o biênio de 1998/2000, tendo como orientador e 'Maestro' o Prof: Eduarde) C. Silveira Marchi, Professor Titular de Direito Romano da Faculdade de Direito da USP, a quem é dedicado este estudo. O trabalho foi merecedor de Menção Honrosa no 8. ${ }^{\circ}$ SIICUSP e o Autor selecionado para participar das atividades de Iniciação Cientifica na Rutgers University - The Stute University of New Jersey, Estados Unidos, em abril de 2001. 


\section{Introdução}

$\mathrm{O}$ exame da figura jurídica da datio in solutum ${ }^{1}$ revela-nos importantes questões controversas. Tais questões são levantadas, uma vez que, desde as fontes romanas, legisladores e doutrinadores têm tratado esta figura jurídica de modo bastante diverso. ${ }^{2}$

Dentre elas, cuidaremos separadamente dos efeitos da dação em pagamento nos casos de credor evicto, que apresentam soluções opostas nos diversos ordenamentos estrangeiros e, especialmente, no Código Civil brasileiro. Essa controvérsia é originária das fontes romanas, destacando-se os textos de Marciano ${ }^{3}$ e Ulpiano. ${ }^{4}$

1. Este é o termo consagrado pelas fontes romanas, sendo utilizado até hoje pela doutrina moderna. Vale lembrar as várias traduções utilizadas pelos autores, designando tal figura como daçăo em pagamento, no Brasil (cf. Beviláqua, Direito das obrigações, $2^{\mathrm{a}}$ ed., Bahia, Livraria Magalhães, 1910, p. 146 e Antunes Varela, Direito das obrigações, v. 2, Rio de Janeiro, Forense, 1978, p. 195; cf., também, Pontes de Miranda, Tratado de direito privado - Parte Especial - Tomo XXV, 3a ed., Rio de Janeiro, Borsoi, 1971, p. 3, que preferiu traduzir a denominação como dação em soluto), dação em cumprimento pela moderna civilística portuguesa (cf. Antunes Varela, Das obrigaç̧̃es em geral, v. 2, $4^{\text {a }}$ ed., Coimbra, Almedina, 1990, p. 160) que considera tal terminologia melhor do que a adotada pela doutrina clássica, ou seja, dação em pagamento (cf. Cunha Gonçalves, Tratıdo de Direito Civil, v. 4, tomo 2, $2^{\mathrm{a}}$ ed., São Paulo, Max Limonad, 1955, p. 824), uma vez que não se trata de pagamento stricto sensu; como dation en paiement na França (cf.

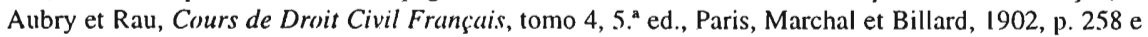
Baudry-Lacantinerie et Barde, Traité Théorique et Pratique de Droit Civil - des obligations, tomo 2, 3." ed., Paris, L. Laros \& L. Tenin, 1907, p. 787), Leistung an Erfüllungsstatt ou Annahme an Erfüllungssstatt pela doutrina moderna alemã (cf. Esser, Schuldrecht-Allgemeiner und Besonderer Teil, 2. a ed., Karlsruhe, C. F. Müller, 1960, p. 306; Espínola, Garantia e extinção das obrigaçiones, Rio de Janeiro, Freitas Bastos, 1951, p. 66, n. 122; e Allara, La prestazione in luogo di adempimento (datio in solutum) in Annali del Seminario Giuridico della Università di Palermo, v. 13, Palermo, Boccone del Povero, 1929, p. 33, n. 1) e como Angabe, Hingabe, Geben ou Gebung an Zahlungsstatt pelo direito germânico, conforme observação de Allara e Carvalho de Mendonça, Doutrina e Prática das Obrigaç̧̃és, v. 1, 4ª ed., Rio de Janeiro, Forense, 1956, p. 579. Os autores italianos utilizam a expressão dazione in pagamento (cf. Bianca, Diritto) Civile, v. 4, Milano, Giuffrè, 1990, p. 431; e Rodotà, Dazione in pagamento (diritto civile) in ED II (1962), p. 734). Bianca e Rodotà, entretanto, acrescentam que o Código Civil italiano de 1942 adotou a expressão prestazione in luogo di adempimento, que fora proposta por Allara, que a considerava mais correta, uma vez que abrangeria prestaçōes de diversa natureza. Ou seja, o termo prestazione in luogo di adempimento é mais amplo, abrangendo a daziome in pagamento "in senso stretto", que significa dar coisa diversa da original (cf. Messineo, Manuale di diritto civile e commerciale, v. 3, $9^{\text {a }}$ ed., Milano, Giuffrè, 1959, p. 271 e Zaccaria, La prestazione in luogo dell'adempimento - fra novazione e negozio modificativo del rapporto, Milano, Giuffrè, 1987, p. 254). Cabe ressaltar que Teixeira de Freitas, Esboso do Código Civil, v. I, 3a ed., Brasília, Fundação Universitária de Brasília, 1983, p. 261, criou uma nova expressão, denominando a figura por pagamento por entrega de bens, uma vez que privilegiou a utilização da língua portuguesa, apesar da grande profusão do termo datio in solutum. Por fim, lembra Zaccaria, op. cit., pp. 8-9, n. 3, no sistema de Common Law, ou direito atlântico, temos a figura do Accord and satisfaction, semelhante à dação em pagamento.

2. Cf. Allara, op. cit. (nota / supra), pp. 29-30.

3. D. $46,3,46$ pr.-1, Marci. 3 regularum.

4. D. 13, 7, 24 pr., Ulp. 30 ad edictum. 
Por conseguinte, faz-se necessária a abordagem sobre a natureza jurídica da dação em pagamento, já que é fator determinante para o tratamento dos casos de credor evicto. O tema da natureza jurídica da datio in solutum é, também, bastante polêmico, conforme veremos posteriormente. Significativo, neste sentido, é o fato da obra de Planiol, ${ }^{5}$ nas diversas edições de seu tratado, ter sofrido alterações a respeito do assunto, adotandose nas últimas edições a tese que veementemente era criticada nas primeiras."

Desse modo, propomo-nos, após investigar a natureza jurídica da dação em pagamento, apresentar as diversas possibilidades de solução existentes para os casos de credor evicto. Além disso, na medida do possível, pretendemos apresentar uma solução de lege ferenda no direito brasileiro, já que, a nosso ver, sua posição destoante da legislação estrangeira não parece ser a ideal.

Por fim, cabe ressaltar a importância do estudo da datio in solutum. Zaccaria, ${ }^{7}$ ao tratar desta figura jurídica, indaga o sentido em analisá-la atualmente, uma vez que seu interesse econômico e social foi bastante diminuído e sua vetustez é notória. ${ }^{8}$ Entretanto, afirma o mesmo autor, a dação em pagamento ocupa uma posição central no sistema de relações obrigacionais.

Desta maneira, salienta Zaccaria, nossa figura relaciona-se com inúmeros outros temas, como a novação, as obrigações facultativas, a cessão de crédito pro soluto e pro solvendo, ao pagamento com sub-rogação, dentre outros. Em suma, representa fecundas possibilidades de estudo, já que remetem a figuras jurídicas clássicas que se

5. Traité élémentaire de droit civil, tomo 2, $4^{\mathrm{a}}$ ed., Paris, LGDJ, 1907, pp. 647-648; e Planiol-RipertBoulanger, Traité élémentuire de droit civil, tomo 2, 3." ed., Paris, LGDJ, 1949, pp. 172-173.

6. Desse modo, como lembram Espínola, op. cit. (nota / supra), p. 68; e Cunha Gonçalves, op. cit. (nota I supra), p. 829; nas primeiras edições da já citada obra, Planiol condena a posição adotada pela maioria da doutrina francesa, ou seja, de que a dação em pagamento implicaria uma novação objetiva (cf. cap. III.2.2). O autor afirma que as partes não constituiriam uma nova obrigação para ser extinta imediatamente. Afinal, a intenção das partes, ao realizar a dação em pagamento, é de apenas extinguir a obrigação primitiva e não de construir uma nova. Além disso, ao tratar dos casos de credor evicto, o autor critica aqueles que consideram o art. 2.308 do Código Civil francês um retrato da relação entre a datio in solutum e a novação objetiva, uma vez que tal artigo considera a prestação primitiva extinta. Entretanto, já nas edições posteriores do Traité élémentuire de droit civil, revistas por Ripert e Boulanger, temos uma alteração completa na sua posição, passando-se a defender a tese de que a dação em pagamento implica uma novação objetiva. A obra passa a afirmar que essa posição é mais lógica e satisfatória do que a posição tradicional, que considera a dutio in solutum como uma modalidade do pagamento, como um modo especial de extinção de obrigações. Salienta-se,ainda, que não pode ser alterado o objeto de uma obrigação sem que ela sofra novação.

7. Op. cit., (nota I supra), pp. 1-2.

8. O estudo da dação em pagamento teve seu grande desenvolvimento no início do século $\mathrm{XX}$, especialmente na Alemanha, onde podemos encontrar inúmeras teses sobre o tema. Cf., dentre outros, 
transformam visando a adequar-se ao moderno pensamento jurídico. A datio in solutum, ainda, devido ao seu papel no sistema, deve ser confrontada com a teoria geral do adimplemento.

\section{Datio in solutum}

1. Aspectos preliminares

O adimplemento das obrigações, no Direito Romano e moderno, é regido pelo princípio "solutio eius quod debetur" presente nas Institutas de Gaio" e Justiniano." Desse modo, o devedor terá de adimplir mediante a prestação devida, não podendo alterá-la segundo a sua vontade e o credor não pode exigir prestação diversa.

Deste princípio romano decorre outro, de Paulo: "aliud pro alio invito creditori solvi non potest" " consagrado pelo art. 863 do Código Civil brasileiro. ${ }^{12}$ Entretanto, pode-se inferir que é possível alterar a prestação devida com o consentimento do credor. Assim, tem-se a datio in solutum, que pode ser definida

Melcher, Gegensatz des Rechtscharakters der Leistung an Erfïllungsstatt und der Leistung Eıfüllungshalber, Borna-Leipzig, Noske, 1903, Friedländer, Wer haftet dem Gläubiger für Mängel einer Sache, die er für die Leistung seines Schuldners von einem Dritten an Erfüllungsstatt angenommen hat?, Greifwald, J. Abel, 1904, Stampe, Das causa-Problem des Civilrechts - eine Rechtspolitische Studie am $\$ 343$ BGB, Greifswald, Julius Abel, 1904, Mickel, Hingabe an Erfiillungsstatt nach dem Bürgelichen Gesetzbuch, Metz, Lang, 1905, Krüsmann, Die juristische Natur der Hingabe an Erfüllungsstatt, BornaLeipzig, Noske, 1906, Epstein, Die Leistung an Erfüllungsstatt nach dem Recht des Bürgerlichen Gesetzbuches, Halle, Kaenmerer, 1913, Meyer-Oelschigk, Die Mängelhaftung bei Datio in solutum /ach/ deutschen und auslïndischen Recht, Borna-Leipzig, Noske, 1935, Ceglarek, Die Folgen einer rechtsmangelhaften Leistung an Erfüllungsstatt, Breslau, Kleinert \& Söhne, 1936, Tegeler, Wenn ist eine Verbindlichkeit an Erfüllungsstatt übernommen? \$ 364 Absatz. II BGB, Lengerich i. W., Lengericher Handelsdruckerei, 1936, Hartmann, Rechts - und Sachmä̈ngel bei der Leistung an Elfiillung.sstutt, Jena, Neuenhahn, 1940. Além disso, cabe ressaltar o estudo de Harder, Die Leistung an Erfülltungs.s Stutt (datio in solutum), Berlin, Duncker \& Humblot, 1976, que, como veremos (cf. cap. III.2.3), inovou em relação à doutrina tradicional alemã.

9. Gai. 3, 168.

10. Inst. $3,29 \mathrm{pr}$.

11. Paul. 28 ad edictum, D. 12, 1, 2, I.

12. "O credor de coisa certa não pode ser obrigado a receber outra, ainda que mais valiosa" $\mathrm{Cf}$. Marky, Curso elementar de direito romano, 8. ed., São Paulo, Saraiva, 1995, p. 147, Pontes de Miranda, op. cit. (nota I supra), p. 5, Serpa Lopes, Curso de Direito Civil, v. 2, 6a ed., Rio de Janeiro, Freitas Bastos, 1995, p. 227, Carvalho Santos, Dą̧ăo em pagamento in REDB 14 (s.d), p. 213, Pugliese, Istituziomi di diritto romamo, Padova, Piccin, 1986, p. 655, e Salkowski, Istitutionen - Grundziige des Systems und der Geschichte des römischen Privatrechts, 9." ed., Leipzig, Bernhard Tauchnitz, 1907, p. 434. 
como a substituição da prestação devida por outra, com o consentimento das partes, extinguindo-se a dívida.

No Direito Romano pós-clássico, Justiniano admitia, para certos casos, devido a difícil situação econômica da época, a datio in solutum necessaria, ${ }^{13}$ que prescindia do consentimento do credor.

Assim, em Nov. 4, 3 de 535, Justiniano introduz a datio in solutum necessaria em favor do devedor de um mútuo que, embora tendo imóveis, não podia pagar a dívida com dinheiro ou móveis. Desse modo, entregaria os imóveis (ou um deles) ao credor, que era obrigado a aceitar, após uma avaliação justa, realizando a datio in solutum. Já em Nov. 120, 6, 2 de 544, tem-se uma determinação particular para os débitos de igrejas e obras pias, que não possam extinguir a dívida pela entrega de móveis ou através da anticrese de imóveis. ${ }^{14}$

Por conseguinte, a datio in solutum necessaria opõe-se à datio in solutum voluntaria, ou seja, creditore consentiente, na qual prevalece a vontade das partes e continua presente no Direito moderno. ${ }^{\text {is }}$ A escassez da moeda, como ainda lembra Pontes de Miranda, ${ }^{16}$ gerava a importância da datio in solutum necessaria.

Cabe citarmos os elementos da datio in solutum, os quais a doutrina traz

13. Cf., dentre outros, Moreira Alves, Direito Romano, v. 2, $5^{\mathrm{a}}$ ed., Rio de Janeiro, Forense, 1995, p. 92, n. 934, Arangio-Ruiz, Istituzioni di Diritos Romuno, 14." ed., Napoli, Jovene, 1984, p. 394, Guarino, Diritto Privato Romano, 8. "a ed., Napoli, Jovene, 1988, p. 720, Girard, Manuel Élémentaire de Droit Romuin, $4^{a}$ ed., Paris, Arthur Rousseau, 1906, p. 686, Marrone, Istituzioni di diritto romano (Ius. Fonti. Processos. Fatti e negozi giuridici. Persone e famiglia. Cose. Diritti reali. Possesso. Obbligazioni. Donazioni. Successioni), Palermo, Palumbo, 1989, p. 7I6, Kaser, Das römische Privatrecht. II. Die nachklassischen Entwicklungen, 2. ${ }^{a}$ ed., München, C. H. Beck, 1975, p. 442, n. 22, Di Marzo, Istituzioni di diritto romano, Milano, Giuffrè, 1938, p. 318, Voci, Istituzioni di diritto romano, 4. a ed., Milano, Giuffrè, 1994, p. 379, n. 2, Burdese, Mantuale di diritto privato romano, 3. a ed., Torino, UTET, 1987, p. 596, Pastori, Elementi di divitto romano - le obbligazioni, Milano, Cisalpino, 1991, p. 241, e Nardi, Radiografia dell'aliud pro alio consentiente creditore in solutum dare in BIDR 73 (1970), p. 72.

14. Cf. Marrone, op. cit. (nota 13 supra), p. 716, Kaser, Das römische Privatrecht II cit. (nota 13 supra), p. 442, n. 22, e Nardi, op. cit. (nota 13 supra), p. 72.

15. Alguns autores (cf. Allara, op. cit. (nota I supra), pp. 78-80) cogitam a existência de uma datio in solutum necessaria no Direito moderno, para os casos de execução forçada. Desse modo, estaria inserta no direito processual, podendo o credor exercitar o seu direito sem o consentimento do devedor. Dentre eles, Dusi, Istituzioni di diritto civile, v. 2, $2^{3}$ ed., Torino, Giappichelli, 1937, p. 61, n. 8, defende que há dação em pagamento necessária para situações excepcionais, como a execução forçada e a herança de imóvel hipotecado. Allara, a nosso ver corretamente, contesta esta teoria, afirmando não ser cabível tal extensão desta figura de Direito contratual para o Direito processual.

16. Op. cit. (nota I supra), p. 4. 
diversamente. ${ }^{17}$ Preferimos a posição de Allara, ${ }^{18}$ mais detalhada e precisa. Desta maneira, podemos identificar cinco elementos essenciais da datio in solutum: a) a preexistência de uma relação obrigacional; b) os sujeitos da datio in solutum; c) o consentimento das partes; d) o objeto (diverso) e; e) a causa.

Muito se discute sobre a extensão da figura da datio in solutum. $\mathrm{O}$ art. 995, do Código Civil brasileiro, refere-se apenas ao caso mais comum, o de rem pro pecunia, ou seja, substituição da prestação pecuniária por uma coisa diversa. A doutrina, ${ }^{19}$ contudo, é clara ao ampliar a interpretação desse artigo, baseando-se nas características da figura, admitindo-se assim qualquer substituição da prestação original mediante $o$ acordo entre as partes.

Por conseguinte, Carvalho Santos ${ }^{20}$ traz, a nosso ver, os casos possíveis de datio in solutum: "a. uma coisa móvel ou imóvel ao invés de uma outra (rem pro re); b. em lugar de dinheiro (rem pro pecunia); c. ou em substituição a um fato (rem pro facto); d. um fato positivo ou negativo do devedor em lugar de um outro fato (factum pro facto); e. ou em lugar de uma coisa (factum pro re); f. ou em lugar de dinheiro (factum pro pecunia); g. um crédito do devedor ou de outra pessoa em vez da coisa (nomen iuris pro re); h. ou em lugar de dinheiro (nomen iuris pro pecunia); i. ou, finalmente, em lugar de um fato devido (nomen iuris pro facto)". ${ }^{21}$

Vale esclarecer que a datio in solutum não se confunde com as obrigações

17. Cf. Allara, op. cit. (nota I supra), pp. 184-187; Serpa Lopes, op. cit. (nota /2 supra), pp. 246247; Pontes de Miranda, op. cit. (nota 1 supra), p. 4, e Carvalho Santos, op. cit. (nota 12 supra), pp. 214 215. Cabe ressaltar que a doutrina brasileira considera um elemento essencial que a nova prestação não seja em dinheiro, devido ao determinado pelo art. 995 do Código Civil brasileiro.

18. Op. cit.(nota I supra), pp. 184-187.

19. Antunes Varela, op. cit. (nota I supra), pp. 196-197, Pontes de Miranda, op. cit. (nota I supra), p. 4, e Carvalho Santos, op. cit. (nota 12 supra), p. 215.

20. Op. cit. (nota 12 supra), p. 215.

21. Pontes de Miranda, op. cit. (nota l supra)., p. 4, cita sete dos casos supra mencionados, não constando os de nomen iuris pro re e nomen iuris pro facto. Já Antunes Varela, op. cit. (nota l supra), p. 196-197, vai além, defendendo o alargamento da dação em pagamento a todos os casos em que uma prestação diversa da devida é aceita e realizada, visando à extinção imediata de uma obrigação. Assim, inclui os casos de substituição de uma prestação de coisa por uma de dinheiro. Tal situação é expressamente proibida pelo art. 995 do Código Civil brasileiro, mas é aceita pela doutrina estrangeira. O autor explica que esta posição obedece a essência da datio in solutum. Crome, System des Deutschen Bürgerlichen Rechts. II. Recht dev Schuldverhältnisse, Tübingen und Leipzig, J.C.B. Mohr, 1902, pp. 262-263, do mesmo modo, afirma que a dação em pagamento pode ter como nova prestação "Sache oder andere Leistung", ou ainda, "eine Forderung" Também concordamos com a opinião de Antunes Varela, apesar da redação do art. 995 do Código Civil que, a nosso ver, deveria ser alterada. Solazzi, L'estinzione della obbligazione, Napoli, Jovene, 1931, pp. 153-154, afirma que a doutrina estrangeira, apesar de controversa, admite esta hipótese. 
alternativas, nem com as facultativas. ${ }^{22}$ Antunes Varela ${ }^{23}$ explica que nestes tipos de obrigação o acordo é anterior, geralmente na constituição da mesma, enquanto que na datio in solutum ocorre no momento da prestação ser cumprida. ${ }^{24}$

O mesmo autor diferencia a datio in solutum da dação pro solvendo. ${ }^{25}$ Tal explicação faz-se necessária quando a nova prestação é um título de crédito, hipótese prevista pelo art. 997, do Código Civil brasileiro, que a classifica como uma cessão de créditos. O cerne desta distinção está na vontade das partes, diferente em ambos os casos.

\section{Natureza Jurídica da datio in solutum}

Como já foi dito, a natureza jurídica da datio in solutum provoca numerosas disceptações. Vale lembrar que também no Direito Romano não há consenso entre os autores, que destacam as soluções dos Sabinianos e a dos Proculianos, as quais examinaremos posteriormente.

Alguns autores ${ }^{26}$ afirmam ainda, que a dificuldade em caracterizar-se a natureza jurídica da dação em pagamento está no fato de alguns ordenamentos ( $v . g ., 0$ Código Civil italiano de 1865) não a terem previsto, gerando aproximações equivocadas com outros institutos. ${ }^{27}$

22. Cf., dentre outros, Villaça Azevedo, Daçāo em pagăamento in ESD 22 (1977), p. 186.

23. Op. cit. (nota l supra), p. 195, n. 12.

24. Pontes de Miranda, op. cit. (nota I supra), p. 4, acrescenta que nas obrigações alternativas, assim como nas facultativas, só ocorre dação em pagamento quando o objeto prestado é diverso de ambas as prestações previstas.

25. Desta maneira, na datio in solutum, o título de crédito entregue pelo devedor visa a extinguir a obrigação no ato, sendo assim os riscos da cobrança deste título assumidos pelo credor. Já na dação pro solvendo, a obrigação só extingue-se com o pagamento efetivo do título, não tendo o credor o risco da cobrança, ou seja, o devedor entrega o título de crédito apenas para facilitar a sua execução e não para extinguir a dívida.Cf. também, dentre outros, Barassi, Istituzioni di diritto civile, $2^{\mathbf{a}}$ ed., Milano, Giuffrè, 1945, p. 381, Chironi, Elementi di diritto civile, Torino, Fratèlli Bocca, s.d, p. 197, Inzitari, Le obbligazioni in Istituzioni di diritto privato, org. por Mario Bessone, $2^{2}$ ed., Torino, G. Giappichelli, 1995, p. 440, Molitor, Schuldrecht. I. Allgemeiner Teil, $8^{2}$ ed., München, C.H. Beck, 1965, p. 134, e Fikentscher, Schuldrecht, 9ª ed., Berlin-New York, Walter de Gruyter, 1997, p. 190.

26. Cf. Rodotà, op. cit. (nota I supra), p. 735, e Grassetti, Datio in solutum in NDI 4 (1938), p. 550.

27. Rodotà, op. cit. (nota I supra), p. 735, justifica a dificuldade da caracterização da datio in solutum na sua aproximação, errônea segundo sua opinião, com a compra e venda e com a novação. Conforme o autor, essa aproximação atendia o interesse econômico das partes, presente nas figuras da novação e da compra e venda, além da conveniência de estender algumas normas destinadas a essas duas figuras à dação em pagamento, que não expressamente prevista pelo ordenamento italiano de 1865 , sendo tratada pelo Código Civil de 1942. 
Para o nosso estudo, como aponta Cunha Gonçalves, ${ }^{2 \times}$ as várias teorias sobre a natureza jurídica da dação em pagamento são de importância fundamental para a discussão dos casos de anulação e de credor evicto na datio in solutum. A natureza jurídica da datio in solutum, continua o autor, é fator determinante, nos casos de credor evicto, para decidir entre a retomada da prestação original, juntamente com suas garantias ou a prestação permanece extinta e o credor conta com a garantia por evicção.

\section{Direito Romano: Sabinianos e Proculianos}

Ao tratar dos modos de extinção das obrigações, Gaio revela a divergência entre os sabinianos e proculianos ${ }^{29}$ quanto aos efeitos da datio in solutum:

28. Op. cit.(nota / supra), p. 825 . Cf. nota 6.

29. Assim, vários autores mencionam a discussão no direito clássico entre as teses sabinianas e as proculianas: cf. Moreira Alves, op. cit. (nota /3 supra), p. 92, Corrêa-Sciascia, Manual de direito romumo, $6^{a}$ ed., São Paulo, Revista dos Tribunais, 1988, p. 175, Chamoun, Instituiçōes de direito romano, $2^{\text {a }}$ ed., Rio de Janeiro, Forense, 1954, p. 301, Pontes de Miranda, op. cit. (nota I supra), p. 15, Espínola, op. cit. (nota 1 supra), p. 72-73, n. 134, Carvalho de Mendonça, op. cit. (nota / supra), p. 585, Beviláqua, op). cit. (nota I supra), p. 146, Allara, op. cit. (nota I supra), p. 33, n. 2, Zaccaria, op. cit. (nota I supra), p. 22-23, n. 16, Cruz, Da Solutio - Épocas Arcaica e Clássica, v. 2, Coimbra, 1962, pp. 122-123, Giorgi, Teoria delle Obbligazioni, v. 7, $7^{\mathrm{a}}$ ed., Torino, UTET, 1927, p. 389, Dernburg, Pandekten. II. Obligationrecht, Berlin, H. W. Müller, 1897, p. 163 (trad. it. de Francesco Bernardino Cicala, Pandette - Diritto delle Obbligazioni, v. 2, Torino, Fratelli Bocca, 1903, p. 239, Windscheid, Lehrbuch des Pandektenrechts. II, Frankfurt, Rütten \& Loening, 1906 (trad. it. de Carlo Fadda e Paolo Emilio Bensa, Diritto delle Pandette. II, Torino, UTET, 1925, p. 316), Astuti, Daziome in pagamento - Diritto romano $e$ intermedio in ED 9 (1962), p. 728, Solazzi, op. cit. (nota 21 supra), p. 155, Longo, Datio in solutum - Diritto romano in NNDI 5 (1957), p. 173, Talamanca, Istituzioni di Diritto Romano, Milano, Giuffrè Editore, 1990, p. 639, Pacchioni, Corso di Diritto Romano, v. 3, Torino, UTET, 1922, p. 144, Perozzi, Istituzioni di Diritto Romano, v. 2, $2^{\text {a }}$ ed., Milano, Vallardi, 1928, p. 416, Jörs-Kunkel-Wenger, Römisches Rrivatrecht-Abriß $\beta$ des römischen Zivilproze.ßBrechts, 3. ${ }^{a}$ ed., Berlin, Springer, 1949, p. 196, Lepointe et Monier, Les obligation.s en droit romain et dans l'ancien droit français, Paris, Sirey, 1954, p. 372, Arangio-Ruiz, op. cit. (nota 13 supra), p. 394, Bonfante, Istituzioni di Diritto Romano, $10^{\mathrm{a}}$ ed., Torino, Giappichelli, 1946, p. 423, Guarino, op. cit. (nota 13 supra), p. 720, Giffard, Précis de Droit Romain, tomo 2, Paris, Dalloz, 1934, p. 238, Girard, op. cit. (nota 13 supra), p. 686, Monier, Manuel Élémentaire de Droit Romain, tomo 2, Paris, Domat-Montchrestien, 1948, p. 220, Kaser, Dus römische Privatrecht. I. Das altrömische, das vorklassische und klassische Recht, $2^{\mathrm{a}}$ ed., München, C. H. Beck, 1971, 1. 638, Biondi, Corso di istituzioni di diritto romano, v. 2, Catania, Siciliana, 1930, p. 158, Leonhard, Allgemeines Schuldrecht des BGB. I, München und Leipzig, Duncker \& Humblot, 1929, p. 594, Marrone, op. cit. (nota 13 supra), p. 716, Volterra, Istituzioni di diritto privato romano, Roma; Ricerche, 1961, p. 604, Burdese, op. cit. (nota 13 supra), p. 596, D'ors, Derecho privado romano, 7." ed., Pamplona, Universidad de Navarra, 1989, p. 444, Cuq, Les institutions juridiques des romains. II. Le droit classique et le droit du bas-empire, Paris, LGDJ, 1908, p. 519, Czyhlarz, Lehrbuch der Institutionen des römichen Rechtes, $13^{\mathrm{a}}$ e $14^{\mathrm{a}}$ ed., Wien und Leipzig, TempskyFreytag, 1914, p. 215, Schulz, Classical Roman Law, London, Clarendon Press, 195I, pp. 629-630, Di Marzo, op. cit. (nota 13 supra), p. 318, Voci, op. cit. (nota 13 supra), p. 379, Villers, Rome et le droit privé, Paris, Albin Michel, 1977, p. 401, Weiss, Institutionen des römischen Privatrechts, 2." ed., Stuttgart, Franz Mittelbach, 1948, p. 434, Sciascia, Istituzioni di diritto romano - Regulae Iuris, 3." ed., Roma, Stamperia Nazionale, 1969, p. 109, Sanfilippo, Istituzioni di dirito romano, 9." ed., Soveria Mannelli, 
Gai. 3, 168: "Tollitur autem obligatio praecipue solutione eius, quod debetur. Unde quacritur, si quis consentiente creditore aliud pro alio solverit, utrum ipso iure liberetur; quod nostris praceptoribus placet, an ipso iure maneat obligatus, sed adversus petentem exceptione doli mali defendi debeat. quod diversae scholae auctoribus visum est"
Gai. 3, 168: "A obrigação, por outro lado, extingue-se principalmente pelo pagamento daquilo que é devido. Sendo que no caso que um, com consenso do credor, tenha pago uma coisa pela outra, entende-se que se libera ipso irre, aqueles que são nossos precedentes, ou entende-se que de pleno direito permanece obrigado, mas devendo defender-se o requerente com a exceptione doli mali, aqueles autores da outra escola"

De um lado, os sabinianos defendiam a tese de que a datio in solutum era uma hipótese de extinção ipso iure da obrigação, ${ }^{30}$ ou seja, agia como fato de eficácia no plano da existência da dívida. De outro yado, os proculianos consideravam a dação em pagamento como uma extinção exceptionis ope da obrigação, devendo, assim, o devedor utilizar a exceptio doli mali para paralisar a actio do credor, agindo a dação no plano da efícácia do crédito.".

Os motivos dessa diferença não são conhecidos. ${ }^{32}$ Segundo Falchi, ${ }^{3.3}$ os proculianos eram presos à tradicional estrutura dos institutos e privilegiavam a identificação dos efeitos jurídicos originários na fattispecie. ${ }^{34}$ Já os sabinianos davam prevalência à pesquisa do escopo perseguido em concreto pelos sujeitos jurídicos ${ }^{35}$

Rubbettino, 1996, p. 305, Puchta, System und Geschichte des römischen Privatrechts, 8. ed., Leipzig, Breitkopf und Härtel, 1875, p. 377, Musumeci, Marciano e gli efferti della 'datio in solutum' (osservazioni su D. 46, 4, 36) in IURA 20 (1969), p. 524, Falchi, Le controversie tra sabiniani e proculiani, Milano, Giuffrè, 1981, pp. 179-182, Baviera, Le due scuole dẹi giureconsulti romani, Roına, "L'erma" di Bretschneider, 1970, p. 91, Ernst, Die Folgen mangelhafter Beschaffenheit der Leistung an Zahlungsstatt nach römischem Recht, Zurich, Orell Füssli, 1890, p. 70.

30. Desta maneira, para os sabinianos o aliud pro alio era uma alteração da solutio, com a mesıma natureza jurídica (cf. Falchi, op. cit. (nota 29 supra), p. 180, e Baviera, op. cit. (nota 29 supra), p. 92). Essa conclusão pode ser conferida em D. 46, 3, 54, Paul. 56 ad edictum.

31. Cf. Pontes de Miranda, op. cit. (nota / supra), p. 15.

32. Cf. Baviera, op. cit. (nota 29 supra), pp. $91-92$.

33. Op. cit. (nota 29 supra), p. 182.

34. Ainda conforme Falchi, op. cit. (nota 29 supra), p. 180, esse apego à tradição dos proculianos initiga a posição do devedor, uma vez que segundo tal escola, este conta apenas com uına defesa processual.

35. Por conseguinte, continua Falchi, op. cit. (nota 29 sitpra), p. 182, alguns principios podem ser identificados: enquanto os proculianos interpretam objetivaınente, sem priorizar o elemento de vontade, os sabinianos utilizaın a ótica subjetiva do escopo da ação, entendendo de modo instrumental as figuras jurídicas da fattispecie. 
Tal controvérsia apenas foi resolvida por Justiniano, ${ }^{36}$ que privilegiou a tese sabiniana, igualando os efeitos da solutio direta e os da indireta: ${ }^{37}$

Inst., 3, 29 pr.: "Tollitur autem omnis obligatio solutione eius quod debetur, vel si quis consentiente creditore aliud pro alio solverit. Nec tamen interest, quis solvat, utrum ipse qui debet an alius pro eo: liberatur enim et alio solvente, sive sciente debitore sive ignorante vel invito solutio fiat. Item si reus solverit, etiam ii qui pro eo intervenerunt liberantur. Idem ex contrario contingit, si fideiussor solverit $i$ non enim solus ipse liberatur; sed etiam reus"
Inst., 3, 29 pr.: "Toda obrigação, por outro lado, extingue-se pelo pagamento daquilo que é devido, ou se, com o consenso do credor, tenha-se pago uma coisa pela outra. Nem importa quem paga, se o mesmo que deve, ou se um outro por ele: libera-se também se paga um outro, esteja o devedor ciente, ignorante ou contra a sua vontade o pagamento. Do mesmo modo, se o devedor tiver pago, também liberam-se aqueles que intervieram por ele. O mesmo, pelo contrário, ocorre se tiver pago o fideiussor: não apenas ele se libera, mas também o devedor".

Além disso, cabe ressaltar que a posição dos sabinianos foi vitoriosa pois eles convertiam o valor da coisa para o seu equivalente em dinheiro, o que fazia a entrega da coisa equivaler ao seu valor, extinguindo o crédito, ${ }^{38}$ como já dissemos, ${ }^{39}$ do mesmo modo que a solutio direta em dinheiro. ${ }^{40}$

36. Analisando tal texto juntamente com o de Gaio, Gai. 3, 168, Silveira Marchi, Concurso de Credores - $e$ pactum ut minus solvatur, Lecce, Edizione del Griffo, 1997, p. 47, n. 27, lembra que o preceito justianianeu é mais pungente, uma vez que utiliza "obligatio" ao invés de "omnis obligatio" e descartou o termo "praecipue"

37. Segundo alguns autores, os proculianos consideravam o pagamento e a datio in solutum figuras distintas, assim como consideravam a permuta distinta da compra e venda. Já os sabinianos confundiam o pagamento com a datio in solutum, do mesmo modo que consideravam a permuta e a compra e venda com princípios unívocos. No Direito justinianeu, foi vencedora a tese proculiana a respeito da permuta e da compra e venda, ou seja, foram consideradas figuras distintas. Contudo, quanto à datio in solutum e ao pagamento, prevaleceu a tese dos sabinianos, identificando assim, a confusão entre aıbas as figuras (cf. Carvalho de Mendonça, op. cit. (nota I supra), p. 585, e Baviera, sp. cit. (nota 29 supra), p. 92). Baviera, entretanto, não acredita que a controvérsia entre os proculianos e sabinianos tivesse essa origem, ou seja, a natureza do preço na compre e venda. Segundo o mesmo autor, na nossa divergência, ambas as escolas admitiam que uma coisa diversa do preço pudesse extinguir a obrigação. Desse modo, a questão resvale sobre a natureza da extinção da obrigação, parecendo ser teórica. Cabe lembrar ainda, a relação deste problema com os casos de credor evicto na datio in solutum. Alguns autores, conforme veremos (cf. cap. IV.1), baseiam sua solução de exegese para os textos de Marciano, D. 46, 3, 46, pr-1, Marci. 3 regularum, e Ulpiano, D. 13, 7, 24 pr., Ulp. 30 ad edictum nessa polêmica entre os sabinianos e proculianos (cf. Ernst, op. cit. (nota 29 supra), p. 70).

38. Cf. Carvalho de Mendonça, op. cit. (nota / supra), p. 585, e Baviera, op. cit. (nota 29 supra), p. 92

39. Cf. notas 36 e 37 supra.

40. Cf. Cruz, on. cit. (nota 29 supra), p. 123. 
Para o nosso estudo, a discussão entre os sabinianos e dos proculianos, além de ilustrar a polêmica sobre os efeitos da datio in solutum, ${ }^{41}$ tem profunda relação com os casos de credor evicto.

\section{Direito Moderno: diversidade de teses}

\subsection{Compra e venda}

A primeira tentativa de estudo da natureza jurídica da datio in solutum, originária do Direito Romano, ${ }^{42}$ equipara-a à compra e venda, ou ainda, à troca (ou permuta) ${ }^{43}$ Essa aproximação é devida à influência da tradição grega helenística, ${ }^{44}$ que igualava as duas figuras. ${ }^{45}$

41. Apesar de sanada essa divergência, já que, desde Justiniano, não se discute os efeitos de extinção ipso iure da datio in solutum (cf. Allara, op. cit. (nota / supra), p. 250, n. 1).

42. Cf., dentre outros, Zaccaria, op. cit. (nota 1 supra), pp. 4-5, n. 3, e Arndts, Lehrbuch der Pandekten II, 5." ed., München, Cotta'schen, 1865, p. 358, que afirma: "Die Annahme an Zahlungsstatt wirktübrigens gleich einem Kaufe, wobei die Schuldsumme als der Kaufpreis gild"

43. Cf. Antunes Varela, op. cit. (nota I supra), p. 207, Espínola, op. cit. (nota I supra), pp. 69-70, Cunha Gonçalves, op. cit. (nota I supra), pp. 827-829, Carvalho de Mendonça, op. cit. (nota I supra), pp. 582-583, e Alves Moreira, Instituiçōes de Direito Civil português - das obrigações, v. 2, Coimbra, F. França Amado, 1911, p. 278.

44. Cf. Nardi, op. cit. (nota 13 supra), p. 114-115, n. 105, Pontes de Miranda, op. cit. (nota 1 supra), p. 12, De Francisci, La dottrina bizantina della "datio in solutum" di fronte al materiale papirologico in Aegyptus 1 (1920), pp. 302-308, e Rabel, Nachgeformte Rechtsgeschäfte - mit Beiträgen zu den Lehren von der Injurezession und vom Pfandrecht in ZSS 28 (1907), pp. 311-379.

45. De Francisci, La dottrina bizantina cit. (nota 44 supra), p. 302, afirma que a doutrina é pacífica em atribuir a aproximação da dação em pagamento à compra e venda no direito romano aos bizantinos. Segundo Steiner, Datio in solutum, München, C. H. Beck, 1914, explica De Francisci, tal equiparação é bizantina, já que eles entendem contractus como acordo de vontades, enquanto que os clássicos definemno como todo negócio que faz nascer uma obrigação tutelada por ação civil ou pretoriana. Por conseguinte, para os clássicos a datio in solutum não poderia ser um contrato, já que extingue uma obrigação. De Francisci concorda que a os bizantinos consideravam a dação em pagamento um contrato com base em um acordo de vontades, apesar de não compartilhar do mesmo conceito de Steiner sobre contrato. Entretanto, essa explicação é apenas dogmática, negligenciando o lado histórico. De Francisci e Rabel, Nachgeformte cit. (nota 44 supra), pp. 312-313, revelam que os papiros de Tenos $\$ 34,1.87-89$, CPR. 1,9 a.27l n. Chr., Amh. 95 a. 109 e Ravennater Pap. Marini 119 v.J.551 igualam a datio in solutum à compra e venda, entendendo que o débito compensava o preço. De Francisci acrescenta que a especificação do preço, essencial no período tolemaico e romano, não era fundamental nesses casos, sendo necessário apenas que o vendedor fosse devedor da pessoa que figura como comprador e a coisa dada substituti a prestação originária. Além desses documentos, suficientes para demonstrar a influência greco-helenística, De Francisci, La dottrina bizantina cit. (nota 44 supra), p. 306 e Rabel, Nachgeformte cit. (nota 44 supra), pp. 317-318 apresentam outros indícios. Nos papiros P. BGU 526 a.86, Flor. 20 a. 127 e P. BGU 636 a. 20 encontramos um contrato de locação de terreno desfigurado, servindo à função de dation in solutum dos frutos. Já em PMeyer 12, I. 15, esclarece De Francisci, La dottrina bizantina cit. (nota 44 supra), p. 307, tem-se uma sublocação por um ano estipulada em pagamento de um débito pré-existente em analogia 
Tal tese foi abandonada pela doutrina no fim do século passado, ${ }^{46}$ uma vez que apresentava inúmeras falhas, as quais explicaremos no decorrer deste capítulo.

Segundo esta teoria a dação em pagamento seria análoga à compra, quando se entrega uma coisa em lugar de dinheiro, e à troca, quando se entrega uma coisa no lugar de outra ${ }^{47}$

Essa semelhança ${ }^{4 x}$ pode ser demonstrada pelo brocardo jurídico romano dare in solutum est quase vendere (ou vicem venditionis obtinet). ${ }^{49}$ Assim, a doutrina entendia que, na datio in solutum, o devedor venderia um bem ao credor visando a compensar o direito do credor sobre o preço, representado pela prestação original..$^{50} \mathrm{E}$ a tese defendida por Alves Moreira. ${ }^{51}$

Entretanto, conforme já dissemos, essa posição a respeito da natureza jurídica da datio in solutum encontra várias críticas.

Aponta-se, freqüentemente, que a compra e venda não abrangeria, v. g., a prestação de fato no lugar de outra prestação de fato, ${ }^{52}$ uma vez que necessariamente tem-se uma coisa e uma contraprestação em dinheiro. Desta maneira, todos os casos

com a compra e venda, o que demonstra a importância dos papiros sobre o contrato de locação. A conclusão de De Francisci, La dottrina bizantina cit. (nota 44 supva), p. 308, tem grande relevo atual. Segundo o autor, essa tradicional aproximação confirma que se pode valer do termo contrato para designar o que para os clássicos era apenas um substituto do pagamento.

46. Cf. Zaccaria, op. cit. (nota / supra), pp. 4-5, n. 3.

47. Cf. Bianca, op. cit. (nota / supra), p. 435.

48. A semelhança com a compra e venda é admitida por Hedemann, Schuldrecht des Bïrgerlichen Gesetzbuches, 3." ed., Berlin, Walter de Gruyter, 1949, p. 121. Ressalta, entretanto, que não se trata de uma verdadeira compra e venda: "Dabei erwächst ein neues Rechtsverhältnis, auf der Einwilligung des Gläubigers beruhend: Er ist z. B. bereit, statt der geschuldeten Geldsumme eine Schreibmaschine in Kauf zu nehmen'. Ein eigentlicher Kauf ist das nicht". Cf., dentre outros, no mesıno sentido, Vigié, Cours élémentaire de droit civil français, t. 2, $3^{\mathrm{a}}$ ed., Paris, Librairie Nouvelle de Droit et de Jurisprudence, 1905, p: 720. No direito brasileiro, a aproximação da datio in solutum à compra e venda pode ser percebida pelo art. 996 do Código Civil, que determina a incidência das normas relativas à compra e venda no nosso instituto (cf. Carvalho de Mendonça, op. cit. (not $/$ l supra), p. 582).

49. Ant., C. $8,44,4$ (de 212 d. C.)

50. Cf. Bianca, op. cit. (nota 1 supra), p. 435.

51. Op. cit. (nota 43 supra), p. 278.

52. Cf. Antunes Varela, op. cit. (nota / supra), p. 208, Zaccaria, op. cit. (nota I supra), pp. 4-5, n. 3, e Rodotà, (p). cit. (nota I supra), p. 736. Além de tal crítica, Antunes Varela defende que a tese da compra e venda não explica a possibilidade do devedor, nos casos de inexistência da dívida, exigir de volta a coisa dada. 
que envolvam a substituição por uma prestação de facere estariam excluídos desta teoria. Allara $^{53}$ também explica que a essa relação entre as duas figuras não pode ser aplicada a todas as hipóteses de datio in solutum, já que em alguns casos torna-se absurda. ${ }^{54}$

Cunha Gonçalves, ${ }^{55}$ dentre outros autores, ${ }^{56}$ também não aceita tal tese. Primeiramente, considera a dação em pagamento totalmente diferente da troca, uma vez que, na figura citada, cada uma das partes entrega uma coisa que lhes pertence, recebendo outra, enquanto que na datio in solutum se considerarmos apenas o devedor entrega uma coisa, ao passo que o credor só recebe a tal coisa. ${ }^{57}$

Por conseguinte, Cunha Gonçalves apresenta uma série de argumentos para distanciar a datio in solutum da compra e venda. Assim, segundo o autor, enquanto a compra e venda é um contrato bilateral, já que o comprador deve entregar o preço e o vendedor, a coisa vendida, a datio in solutum é um contrato unilateral, pois apenas o devedor deve a coisa em pagamento. Contra tal raciocínio, Enneccerus-Lehınann ${ }^{5 x}$ explicam que, enquanto o devedor cede a coisa, o credor cede o crédito, sendo assim, um contrato bilateral oneroso como a compra e venda.

Além disso, aponta, ainda, a diferença de tratamento nos dois contratos para os casos de evicção, uma vez que na compra e venda, o vendedor deve ressarcir o comprador com o valor do preço (e não-entregar outra coisa igual), ao passo que na datio in solutum, temos o renascimento da prestação primitiva, não sendo possível, apesar da dação ser válida, a ação de evicção por parte do credor evicto."

53. Op. cit. (nota / supra), p. 40.

54. Desse inodo, Allara, op. cit. (nota / supra), p. 40, cita, 1: g., o caso do objeto da prestação primitiva ser uma coisa corporal e a nova prestação ser pecuniária ou quando o objeto da prestação devida seja um facere, o que poderia levar a um contrato inominado com imediata compensação. Assim, o autor defende uma construção menos artificial, que corresponda à intenção das partes e todas as várias hipóteses dessa vontade.

55. Op. cit. (nota I supra), p. 829.

56. Cf., dentre outros, Scuto, Istituzioni di diritto privato, $2^{\mathbf{a}}$ ed., Napoli, Jovene, 1938, p. 557.

57. Esse apontamento também encontra paralelo em Pontes de Miranda, op. cit. (nota / supra), p. 8 , que afirına não se tratar de troca a diıtio in solutum, pois não podemos falar em transmissão da coisa devida ao devedor, frente à transmissão da coisa dada pelo devedor ao credor. Entretanto, apesar da crítica dos autores e da notável artificialidade dessa construção, nāo nos parece inaceitável visualizar a transmissāo da coisa devida ao devedor, frente à transmissão da coisa dada pelo devedor ao credor na datio in solutum.

58. Recht der Schuldverhältnisse, 15." ed., Tübingen, J.C.B. Mohr, 1958, p. 263.

59. Essa diferença explicitada por Cunha Gonçalves, op. cit. (nota / supra), p. 829, só pode ser considerada com base no art. 998 do Código Civil brasileiro, citado pelo próprio autor. 
Uma diferença essencial, apontada por vários autores, ${ }^{(1)}$ é que a datio in solutum é um contrato de natureza real, enquanto que a compra e venda, como sabemos, é consensual. Assim, a compra e venda tem na transmissão da propriedade da coisa uma mera conseqüência do contrato, já que se trata de um contrato consensual. Já a datio in solutum, por sua vez, tem na dação da coisa um elemento essencial, uma vez que só produzirá efeitos após a traditio, com a transmissão da propriedade, pois se trata de um contrato de formação real.

A nosso ver, entretanto, a principal diferença entre a figura da datio in solutum e o contrato de compra e venda é a diversidade de causa entre ambos. Assim, enquanto o primeiro tem o nítido intuito de solver uma obrigação, o segundo visa a contrair obrigações, o que torna as figuras bastante diversas. ${ }^{61} \mathrm{Bianca}^{62}$ defende, justamente, que essa tese a respeito da natureza jurídica foi afastada pela doutrina, devido a constatação que a datio in solutum não possui a mesma causa da compra e venda. Allara ${ }^{63}$ vai além, afirmando estar abandonada esta teoria pela doutrina, porque apesar desta construção ser juridicamente possível, é totalmente inaceitável, não encontrando respaldo nas fontes, na lei e, ainda, na vontade das partes, que não têm tal intuito na datio in solutum. Além disso, a aproximação destas duas figuras nas fontes romanas deve-se ao caráter oneroso de ambas. ${ }^{64}$

60. Messineo, op. cit. (nota I supra), p. 272; Cunha Gonçalves, op. cit. (nota I supra), p. 829; Colin et Capitant, Cours élémentuire de droit civil français, tomo 2, $10^{\text {a }}$ ed., Paris, Dalloz, 1953, p. 649, e Lacerda de Almeida, Dos effeitos das obrigações, Rio de Janeiro, Freitas Bastos, 1934, pp. 250-251, que acrescenta, que no caso da dívida originária não-existir, na compra e venda a transferência da propriedade permanece, sendo exigível o preço. Já na dação em pagamento, perde-se a sua causa, podendo ser repetida a própria coisa.

61. Vários autores apontam essa divergência fundamental entre os dois institutos em questão. Rodotà, op. cit. (nota l supra), p. 736, afirma que a datio in solutum e a compra e venda têm diferenças essenciais, ressaltando que a primeira só ocorre com o intuito de solver uma dívida preexistente, não estando presente tal intuito na compra e venda, ou seja, os institutos possuem causas completamente diversas. Do mesmo modo, Grassetti, Datio in solutum - Diritto Civile in NNDI 5(1957), p. 174 e Datio in solutum in NDI cit. (nota 26 supra), p. 550, explica que enquanto o primeiro é um contrato essencialmente liberatório, o segundo é um contrato que visa a contrair obrigações. Em outras palavras, a datio in solutum é um instituto distrahendi ou solvendi causa, enquanto que compra e venda, ou permuta, são contratos contrahendi causa. Segundo autor, essa é a mesına diferença entre a dação em pagamento e a cessão de bens ao credor. Bianca, op. cit. (notı I supra), p. 435, também utiliza o argumento da diversidade entre as causas para afastar os dois institutos.

62. Op. cit. (nota I supra), p. 436.

63. Op. cit. (nota / supra), p. 35.

64. A extinção do crédito nessa tese, esclarece Allara, op. cit. (nota l supra), pp. 35-37, baseia-se na compensação, o que também não está presente nas fontes. Na verdade, as fontes são opostas a esta afirınação, 
Desta maneira, considerando demonstrada ser falsa a identificação da datio in solutum com a compra e venda, permuta ou um contrato inominado, Allara ${ }^{6.5}$ acrescenta que a analogia entre as duas figuras é inexata e perigosa. Afinal, as estruturas jurídicas de ambas apresentam profundas diferenças, lembrando que a única semelhança é a onerosidade, presente na maioria dos negócios jurídicos. Por conseguinte, é uma questão de interpretação da vontade a classificação entre uma dação em pagamento e uma compra e venda. Um critério coerente de interpretação, segundo o autor, é o tratamento dado pelas partes à relação entre a prestação nova e a extinção da antecedente. Assim, no caso de uma relação de mera coincidência cronológica, temos uma compra e venda. Já nas situações de uma relação de causalidade, temos a datio in solutum.

\subsection{Novação}

Segundo doutrina francesa dominante, ${ }^{66}$ a dação em pagamento tem como natureza jurídica a novação. Assim, como afirmam Aubry et Rau ${ }^{67}$ a datio in solutum implicaria uma novação expressa ou tácita operada entre as partes, uma vez que houve a substituição da prestação primitiva por uma outra. ${ }^{6 \times}$

uma vez que a extinção da relação obrigacional dá-se com o efetivo adimplemento da nova prestação. Por conseguinte, Allara defende ser necessário para tal identificação da datio in solutum com a compensação uma idêntica evolução histórica da eficácia extintiva das duas figura, o que não ocorreu. Por outro lado, o mesmo autor considera que as figuras são realmente próximas na legislação italiana. Cf., no mesıno sentido, Zaccaria, op. cit. (nota / supra), pp. 4-5, n. 3, que critica a complexidade desta teoria, ao envolver, além da compra e venda, a figura da compensação.Já a respeito do intuito das partes na datio in solutum, Allara também afirma ser preciso o afastamento das duas figuras. $O$ autor explica que não há o elemento preço na datio in solutum, nem a vontade de extinguir o crédito primitivo sem o adimplemento do novo: "Può dirsi veramente che il debitore miri ad un prezzo? Risponde all'intento delle parti che il raporto obbligatorio si estingua in virtù del semplice accordo senza l'effetivo adempimento della nuova prestazione? A queste domande la risposta non può essere che negativa". Além disso, Allara considera a aproximação da datio in solutum com a compra e venda como uma atividade criativa da jurisprudência, que privilegiou o aspecto econômico.

65. Op. cit. (nota I supra), pp. 40-42.

66. Cf. Espínola, op. cit. (nota I supra), p. 67, Cunha Gonçalves, op. cit. (nota I supra), p. 282, e Baudry-Lacantinerie et Barde, op. cit. (nota I supra), p. 788.

67. Op. cit. (nota I supra), p. 258.

68. Pacifici-Mazzoni, Istituzioni di diritto civile italiano, v. 4, $5^{\mathrm{a}}$ ed., Torino, UTET, 1927, p. 540, tambéme é adepto da tese que a datio in solutum implica novação. Por sua vez, Huc, Commentuire théorique \& pratique du Code Civil, v. 8, Paris, Cotillon, [89.5, p. 46, concorda com tal tese, afirmando não importar que a execução da nova obrigação seja imediata ou posterior, o que levaria a uma novação propriamente dita. Larombière, Theorie et pratique des obligations, tomo 4, Paris, A. Durant et Pedore-Lauriel, 1885, p. 131, também defende esta tesé, porque, segundo o autor, "dans la dation en payement, datio in solutum, 
Desse modo, a dação em pagamento extingue a antiga obrigação, através da constituição de uma nova, que é resolvida concomitantemente com o próprio pagamento, ou seja, de imediato." Devemos acrescentar ainda, que a datio in solutum seria, então, uma novação tácita e objetiva, já que teríamos a alteração do objeto da obrigação. ${ }^{70}$ Além disso, vale lembrar que essa rapidez na formação e na extinção dessa obrigação não modifica a sua natureza de novação.

Segundo De Page, ${ }^{71}$ o ponto de partida da teoria da novação remonta ao Direito Romano, que considera o objeto um elemento essencial da obrigação. Assim, a mudança de seu objeto levaria, necessariamente, à constituição de uma outra obrigação.

Como dissemos, o ordenamento francês acolheu essa teoria sobre a natureza jurídica da datio in solutum. Por conseguinte, ao tratar dos casos de credor evicto na figura, excluiu a possibilidade de renascimento de prestação primitiva, uma vez que um dos efeitos da novação é, justamente, a extinção da antiga obrigação. ${ }^{72}$

Allara ${ }^{73}$ afirma que, segundo essa tese, há uma incompatibilidade jurídica entre a substituição da prestação e a subsistência da relação obrigacional originária.

il y a toujours une novation expresse ou tacite". Ainda, podemos citar como defensores da tese da novação: Colin et Capitant, op. cit. (nota 60 supra), p. 647, Josserand, Cours de droit civil positiffrangais, v. 2, 2a ed., Paris, Sirey, 1933, p. 493, Casati-Russo, Manuale del diritto civile italiano, Torino, UTET, 1950, pp. 432-433 e, mais modernamente, Huet, Traité de droit civil - sous la direction de Jacques Ghestin, Paris, LGDJ, 1996, pp. 65-66.

69. Cf. Antunes Varela, op. cit. (nota I supra), p. 207. Ainda, Baudry-Lacantinerie et Barde, op. cit. (nota I supra), p. 788, afirma que analisando a datio in solutum pode-se distinguir a convenção de dação em pagamento da sua execução, reconhecendo-se neste período intermediário a constituição de uma nova obrigação.

70. Cf. Cunha Gonçalves, op). cit. (nota I suprat), p. 282.

71. Traité élémentaire de droit civil belge, tomo 3, 3. ${ }^{a}$ ed., Bruxelles, Établissements Émile Bruylant, 1967, p. 509.

72. Cunha Gonçalves, op. cit. (nota / supra), p. 282, é bastante claro ao apontar a relação entre a doutrina francesa e os casos de credor evicto, uma vez que devido a essa posição quanto à natureza jurídica da datio in solutum, o credor nāo poderá reviver a prestação primitiva. Desse modo, o art. 2.038 do Código Civil francês, corroborando a posição da dation in solutum como uma novação, deterınina ao devedor prestar garantias por eviç̧ão como um vendedor. O autor, contudo, não concorda comn tal teoria, como veremos em seguida, apresentando suas falhas, segundo sua própria visão. Por fim, podemos resumir as consequiências da adoção da teoria da novação nas explicações de De Page, op). cit. (nota $7 /$ supr(a), p). 511. Segundo o autor, nesta tese, a garantias da obrigação antiga são definitivamente extintas, não podendo executar os antigos prestadores garantias. Do mesmo modo, as cauções também estão liberadas. Além disso, como já dissemos, o credor evicto terá somente a ação de garantia análoga a da compra e venda.

73. Op. cit. (nota / supra), p. 44. 
Essa substituição seria um indicador inequívoco no animus novandi, além da nova prestação estar relacionada a uma nova e distinta obrigação. ${ }^{74}$

Mais recentemente, houve uma revisão da teoria da novação, passandose a considerar uma combinação de várias figuras jurídicas. ${ }^{75}$ Desta maneira, segundo alguns autores, a datio in solutum compreenderia uma novação e um pagamento. ${ }^{76}$ Já conforme outros autores, nossa figura consistiria em uma novação que precederia uma compra e venda ou troca. ${ }^{77}$ Em outras palavras, esta parte da doutrina defende uma natureza jurídica mista para a dação em pagamento. ${ }^{78}$

A tese de que a dação em pagamento implica uma novação tem e sempre teve críticos ferrenhos.

Antunes Varela ${ }^{79}$ critica tal tese ao afirmar que a novação não se identifica na datio in solutum, uma vez que não podemos perceber a intenção das partes em

74. O autor não-considera correto inferir uma impossibilidade de conciliar a substituição da prestação e a subsistência da relação obrigacional originária. Afinal, se a prestação constitui um elemento essencial na obrigação, também é verdadeiro que a obrigação não se restringe a ela, restando o elemento formal, jurídico. Desse modo, Allara, op. cit. (nota I supra), p. 48, pergunta: "Ora, per qual motivo dovrebe negarsi, in Diritto moderno, alle parti di poter cambiare il primo elemento, mantenendo integro il secondo?"

75. Cf. Bianca, op. cit. (nota I supra), p. 436 e Grassetti, Datio in solutum in NNDI cit. (nota $6 /$ supra), pp. 174-175.

76. Segundo Savatier, Cours de droit civil, tomo 2, 2." ed., Paris, LGDJ, 1949, p. 252 e Bénabent, Droit Civil - Les obligations, 3. ${ }^{a}$ ed., Paris, Montchrestien, 1991, p. 351, a datio in solutum tem uma natureza mista, compreendendo uma novação, com a substituição da obrigação antiga por uma nova com o objeto diferente, e um pagamento, com a execução imediata da nova obrigação. Grassetti, Datio in solutum in NNDI cit. (nota 61 supra), pp. $174-175$ e Datio in solutum in NDI cit. (nota 26 supra), p. 550, critica esta solução que considera a datio in solutum como um acordo que modifica o objeto da obrigação, seguido de un adimplemento imediato, o que, segundo o autor, não se adaptaria com perfeição ao ordenamento italiano.

77. Cf. De Page, op. cit. (nota 7I supra), p. 509. De Filippis, Corso completo di diritto civile italiano comparato, v. 5, $2^{\mathrm{a}}$ ed., Milano, Società Editrice Libraria, 1910, pp. 316-317, defende esta teoria. Segundo o autor, a dação em pagaınento tem como natureza jurídica uına novação sob forma de venda ou troca, conforme o seu caso (rem pro pecunicl e rem pro re, respectivamente. Cf. cap. III.2.1). Assim, a nova obrigação constituída pela novação seria uma compra e venda ou uma troca.

78. Bianca, op. cit. (nota I suipra), p. 436 e Grassetti, Datio in solutum in NNDI cit. (nota 6I supra), p. 174-175 e Datio in solutum in NDI cit. (nota 26 supra), p. 550 lembram ainda a solução que defende que a nova obrigação tem como fundamento a renúncia do credor ao seu crédito. Essa é a posição de Larenz, Lehrbuch des Schuldrechts. I. Allgemeiner Teil, 14. ${ }^{2}$ ed., 1987, p. 248, que será explicitada na crítica do autor à posição da doutrina alemã quanto ao $\$ 365$ do BGB (cf. cap. III.2.3). Bianca critica tal teoria, pois considera que ela não demonstra a função solutória da datio in solutum, na verdade a sua principal função. Afinal, segundo o autor, o credor não renuncia ao seu crédito, pelo contrário, tem a sua realização, mesmo que por uma prestação diversa.

79. Op. cit. (nota I supra), p. 207. 
construir uma nova obrigação, mas apenas a de extinguir a obrigação, através de uma prestação diversa da original. ${ }^{80}$ Teríamos, então, a mesma obrigação com somente uma prestação diferente. ${ }^{81}$ Além disso, finaliza o autor, tal equiparação seria inadmissível no direito civil brasileiro, pois o art. 998 do Código Civil, ao determinar o renascimento da prestação primitiva, afasta a novação, que extinguiria a prestação primitiva. ${ }^{x 2}$

Também Cunha Gonçalves ${ }^{83}$ critica a solução francesa, considerando-a inaceitável. Primeiramente, afirma que não existir, nem na doutrina, nem em qualquer legislação, a novação por mudança de objeto, mas apenas por alteração de credor ou devedor, ou ainda pela mudança da própria dívida. ${ }^{84} \mathrm{O}$ autor não-considera a dação em pagamento uma nova dívida, mas apenas um pagamento como outro qualquer, com outra forma. ${ }^{8.5}$

80. Schöninger, Die Leistungsgeschïfte des bürgerlichen Rechts, Tübingen, J. C. B. Mohr, 1906, p. 276, difere a dação em pagamento da novação, pois a última não é solvendi causa, ou seja, as partes não tem a intenção de, somente, extinguir uma obrigação.

81. Pontes de Miranda, op. cit. (nota I supra), p. 4, apresenta crítica semelhante a esta, uma vez que considera um equívoco a posição dos juristas franceses que defendem a natureza jurídica da datio in solutum como uma novação, considerando mais absurdo ainda a afirmação da dação em pagamento implicar novação. Pontes de Miranda justifica tal crítica pois, segundo o próprio autor, não há na datio in solutum a substituição da dívida, mas apenas a substituição da prestação. Cf., no mesmo sentido, Galgano, Diritto civile e commerciale, v. 2, tomo I, Padova, CEDAM, 1990, p. 89, Ravà, Istituzioni di diritto privato, Padova, CEDAM, 1938, p. 413 e Lacerda de Almeida, op. cit. (nota 60 supra), p. 247. Segundo este último autor, na dação em pagamento há a permanência da obrigação, que desaparece na novação, substituindo-se apenas o objeto do pagamento, havendo uma "subrogação de coisas". Do mesıno modo, afirma Messineo, op. cit. (nota I supra), pp. 581-582, acrescentando que a datio in solutum pertence à fase de adimplemento, enquanto que a novação objetiva refere-se à fase constitutiva, já que na primeira, "il soggetto dà" e na segunda, "una delle parti promette".

82. Essa crítica, entretanto, nos parece muito frágil, já que a solução adotada pelo art. 998 não é aceita nos ordenamentos estrangeiros, especialmente no Código francês, país em que a tese da novação possui sua maior força.

83. Op. cit. (nota I supra), pp. 826-827.

84. A afirmação de Cunha Gonçalves, de não existir a novação por mudança de objeto, não pode ser considerada correla. Dentre outros autores, Orlando Gomes, Obrigaçĩes, $17^{\mathrm{a}}$ ed., Rio de Janeiro, Forense, 1998, p. 139, é claro ao explicar a novação objetiva, explicitando que uma de suas causas é a alteração do objeto principal da obrigação. $O$ autor ainda cita um exemplo dessa novação, a substituição da entrega de uma determinada coisa pela prestação de um serviço. Desse modo, esse arguınento apresentado por Cunha Gonçalves não pode ser considerado um obstáculo a teoria que a dação em pagamento implica em uma novação.

85. Por sua vez, Venzi, Notas a Pacifici-Mazzoni, Istituzioni di Diritto Civile Italiano, v. 4, $5^{\mathrm{a}}$ ed., Torino, UTET, 1927, p. 616, n. g, também condena tal solução, afirmando poder apenas ser aplicada para os casos de datio in solutum imprópria, ou seja, nos casos em que o devedor dá em pagamento um novo crédito, substituindo a antiga obrigação por outra. Já na datio in solutum própria, quando o devedor entrega uma coisa corpórea, segundo o mesmo autor, não há uma substituição de uma obrigação por outra, mas sim a satisfação do credor mediante a entrega da coisa. 
Outro crítico de tal tese é Rodotà. ${ }^{x / 1}$ O autor explica que apesar de parte da doutrina aceitar integralmente a teoria de ser a datio in solutum um equivalente da prestação original, sendo assim difícil distinguir a dação em pagamento da novação, isso ocorre porque tais autores consideram que as figuras difeririam apenas quanto à qualidade do bem recebido pelo credor. Na verdade, tais figuras distinguir-se-iam no modo de execução da prestação original. Desta maneira, segundo o autor, enquanto a datio in solutum extingue a obrigação primitiva sem a instituição de uma nova, a novação tem como característica justamente a constituição de uma nova obrigação. ${ }^{87}$ Em outras palavras, a dação em pagamento provoca uma modificação permanente e imediata no campo patrimonial, tanto do credor quanto do devedor, devendo ser ressaltado o conteúdo de direito real presente na datio in solutum. ${ }^{88}$

Além disso, Allara ${ }^{89}$ afirma que o surgimento de uma nova obrigação e o seu imediato adimplemento é uma construção artificial ${ }^{\text {\%) }}$ e contrária ao intuito das partes. Afinal, a substituição da prestação implicaria a extinção da relação obrigacional, que é vista como independente da execução da nova prestação, configurando a datio in solutum como "prestazione dietro rinuncia" del credito originario"2 “

86. Op. cit. (nota / supra), p. 736.

87. Rotondi, Istituzioni di Diritto Privato, Padova, CEDAM, 1937, p. 405, também distingue a datio in solutum da novação. Segundo o autor, a novação objetiva consiste em uma declaração expressa e bilateral das partes em substituir a primeira por uma nova obrigação. Já a dação em pagamento “presuppone invece l'estinzione attuale della obbligazione con prestazione diversa da quella originaria, ma consentita dal credittore". No mesmo sentido, Trabucchi, Istituzioni di diritto civile, 5ª ed., Padova, CEDAM, 1950, p. 471, e Perlingieri, Codice civile annotato con la dottrina e la giurisprudenza, v. 4, Napoli, Edizioni Scientifiche Italiane, 1991, p. 26.

88. Também compartilha dessa posição Bianca, op. cit. (nota I supra), p. 436, que considera a datio) in solutum essencialmente diversa da novação objetiva. Do mesmo modo, Nicolò, L'adempimento dell'obbligo altrui, Milano, Giuffè, 1936, p. 249, ressalta o caráter de direito real da datio in solutum. Segundo esse mesmo autor, a dação em pagamento acarreta um aumento definitivo no patrimônio do credor, seja ele devido a uma transferência de direito ou da realização de uma atividade, enquanto que a novação cria um novo direito.

89. Op. cit. (nota I supra), pp. 48-49.

90. Taınbém De Page, op. cit. (notı 7/ supra), p. 513, considera a tese da novação artificiosa, uına construção jurídica abusiva.

91. Cf. nota 94 supra.

92. Allara (op. cit. (nota I supra), p. 48. Desse modo, segundo o mesmo autor, não se verifica os efeitos reais da dação em pagamento que, na verdade, diferencia-se da novação, pois remete à relação entre a nova prestação e a renúncia ao crédito originário e não à relação entre a últiıma e a obrigação de efetuar a prestação. Por conseguinte, na hipótese de não execução da nova prestação ou desta tornar-se impossível, na datio in solutum, o credor tem o direito de retornar à prestação original, afastando a renúncia. Já na novação, esse direito não é admitido, uma vez que a nova obrigação extingue completamente a primitiva. 
2.3. Modalidade de pagamento: Theorie des Änderungsvertrages e Theorie des Erfüllungsvertrages

A doutrina dominante no Direito alemão considera a datio in solutum como um modalidade do pagamento.".3 Assim, a datio in solutum basear-se-ia no ato de cumprimento da obrigação, que teria o seu objeto modificado pelas partes. Por conseguinte, a dação agiria do mesmo modo do pagamento, extinguindo a obrigação originária. ${ }^{\text {\- }}$

Cunha Gonçalves ${ }^{25}$ considera essa tese como sendo a mais correta, citando ser esta a posição de Planiol, em suas primeiras edições, como já explicamos. Conforme o autor, o próprio nome datio in solutum revela ser, tal figura, uma modalidade de pagamento. A datio in solutum seria apenas uma convenção acessória, que modifica o modo de execução da obrigação, permitindo ao devedor, após aceitação do credor, entregar coisa diversa da avençada originalmente, dando o credor a quitação. Desse modo, não temos uma nova obrigação, mas apenas o pagamento e a extinção da obrigação original, ou seja, não há como se falar em novação.

Além disso, o autor entende que, como se trata de um pagamento, a sua anulação ou os casos de credor evicto implicariam o renascimento da prestação primitiva. ${ }^{\% 6}$ Lembra ainda ser esta é a posição do Direito brasileiro, que, mediante o art. 998 do Código Civil, determina o restabelecimento da obrigação primitiva, não tendo efeito a quitação, excetuando quando houver convenção em contrária. ${ }^{97}$

93. Cf. Antunes Varela, op. cit. (nota / supra), p. 207.

94. O próprio autor, Antunes Varela, op. cit. (nota / supra), p. 207, entretanto, critica tal tese, baseandose no art. 998 do Código Civil, afirmando ser contraditório o renascimento da prestação original previsto pelo artigo supracitado e a modificação do objeto efetuada pela datio in solutum, uma vez que se as partes acordaram para modificar a prestação, não se cogitava o restabelecimento da inesıno. Vale leınbrar que essa crítica só é válida para o Direito brasileiro, já que na Alemanha, $v$. g., onde a tese da modalidade de pagamento é dominante, o $\$ 365$ do BGB não prevê o renascimento da prestação antiga, mas sim a prestação da garantia de evicção como se fosse uın compra e venda.

95. Op. cit. (nota 1 supra), pp. 829-830.

96. Vale leınbrar que Cunha Gonçalves, op. cit. (notu I supral), p. 829, considera a evicção nos casos de datio in solutum, de certo modo, uma anulação da dação em pagamento. Deve-se esclarecer que, de forma alguma, podemos confundir evicção com anulação da dação em pagamento, como salienta Espínola, op. cit. (nota I supra), p. 76. As duas situações podem, em determinados ordenamentos, v.g., no Código Civil brasileiro, terem os mesmos efeitos, o que não significa que são a mesıma coisa.

97. Cunha Gonçalves, op. cit. (nota I supra), p. 829, cita o art. 1.107 do Código Civil brasileiro e o art. 303 do Anteprojeto do Código de Obrigações. Infelizmente, não podemos perceber com clareza qual a intenção do autor quando cita o art. 303 do Anteprojeto do Código de Obrigações, que claramente se opõe ao art. 998 do Código Civil, uma vez que não restabelece a prestação primitiva nas casos de evicção, ressalvando convenção em contrário. 
De Page ${ }^{28}$ também defende tal teoria, afirmando que há na dação em pagamento um efeito mais radical do que o da novação. Trata-se, propriamente, de uma modalidade de pagamento, que altera a obrigação sem afetar os direitos do credor e do devedor:

Ainda, nos casos em que o devedor efetiva a datio in solutum por erro, ou por não ser ele realmente devedor, essa posição de modalidade de pagamento como natureza jurídica proporcionaria, ressalta ainda Cunha Gonçalves, "') o renascimento da prestação primitiva. Se, entretanto, fosse adotada a posição da compra e venda, o devedor (ou vendedor) não poderia reclamar a coisa dada em pagamento, mas apenas o seu valor em dinheiro.

Como dissemos, essa tese é a dominante no Direito alemão adotada por, dentre outros, Leonhard, ${ }^{1(1)}$ Esser, ${ }^{101}$ Esser-Schmidt, ${ }^{102}$ Blomeyer, ${ }^{103}$ Endemann ${ }^{104} \mathrm{e}$ Gernhuber. ${ }^{105}$ Desse modo, a doutrina germânica considera a datio in solutum um contrato modificativo, por meio do qual se altera o objeto da obrigação, sendo que a extinção desta relação obrigacional se dará com o adimplemento do débito conforme foi modificado. Zaccaria ${ }^{106}$ afirma que a doutrina francesa mais moderna também preferiu essa solução. É a chamada Theorie des Änderungsvertrages, ou seja, dos contratos modificativos.

98. Op. cit. (nota 7I supra), p. 513.

99. Op. cit. (nota I supra), p. 829

100. Op. cit. (nota 29 supra), pp. 596-597.

101. Op. cit. (nota I supra), p. 306, também defende a datio in solutum como modalidade de pagamento, seguindo a doutrina alemã dominante "Es handelt sich somit um einen Schuldänderungsvertrag, zu welchem freilich hinsichtlich der Mängelhaftung infolge der Bestimmung des $§ 365$ gewisse novierende Elemente hinzutreten"

102. Schuldrecht. I. Allgemeiner Teil, 6." ed., Heidelberg, C. F. Müller, 1984, pp. 261-262: “Die Vereinbarung der Hingabe und Annahme einer Leistung an Erfüllungs Statt setzt als inhaltsändernder Vertrag Geschäftsfähigkeit und die sonstigen rechts geschäftlichen Wirksamkeitselemente voraus; die dahingehenden Erkärungen sind bei Willensmängeln anfechtbar"

103. Allgemeines Schuldrecht, $4^{\mathrm{a}}$ ed., Berlin, Franz Vahlen, 1969, pp. $231-233$.

104. Lehrbuch des Bürgerlichen Rechts. I. Einleitung - Allgemeiner Teil - Recht der Schuldverhiiltnisse, $9^{\mathrm{a}}$ ed., Berlin, Carl Hehmanns, 1903, p. 806.

105. Die Eifüllung und ihre Surrogate in Handbuch des Schuldrechtes III, Tübingen, J.C.B. Mohr, 1983, pp. 180-183.

106. Op. cit. (nota I supra), pp. 6-7, n. 3. O autor lembra, ainda, que os autores franceses mais recentes, ao adotarem esta tese que define a datio in solutum como tima forma de pagamento, aproximaramse da doutrina francesa mais antiga, que também defendia esta solução. 
Tal teoria foi questionada por Harder, ${ }^{107}$ que define a dação em pagamento como um negócio solutório, que não-gera direitos ou deveres. Sua conclusão depende da relação original, que apenas extinguir-se-á com a satisfação do interesse do credor. Esta é a Theorie des Erfüllungsvertrages. Larenz ${ }^{108}$ concorda com essa teoria, ${ }^{109}$ criticando a Theorie des Änderungsvertrages, ${ }^{111}$ afirmando que esta não foi a adotada pelo BGB.

Conforme vimos anteriormente ${ }^{111}$ Bianca $^{112}$ critica essa posição de Larenz. Além disso, critica também a tese de que a datio in solutum é uma modalidade de pagamento, ou seja, um contrato que modifica o conteúdo da obrigação original, convertendo tal obrigação em uma outra prestação diversa. Segundo este mesmo autor, a datio in solutum não modifica o conteúdo da obrigação original. Ou seja, a nova prestação seria, na verdade, fruto da faculdade conferida às partes, não incidindo sobre as posições do débito e crédito originais. Desse modo, a prestação devida permanece sendo a originária.

\subsection{Outras teses}

Como pudemos perceber, a natureza jurídica da dação em pagamento é bastante controversa. As tradicionais soluções adotadas pela doutrina, de que a datio in solutum remeteria a uma novação, à compra e venda ou a uma modalidade de pagamento, conforme já explicamos, apresentam grandes falhas. Entendemos que, diante de tantos argumentos controversos, qualquer defesa de alguma das teses citadas tornase frágil e equivocada.

107. Op. cit. (nota 11 supra), passim.

108. Op. cit. (nota 78 supra), pp. 248-249.

109. Op. cit. (nota 78 supra), p. 248. Segundo o autor, a teoria de Harder, op. cit. (nota $1 /$ supra), passim, é a mais justa: "Dem wird am ehesten die von Harder aufgestellte Theorie des Erfüllungsvertrages gerecht. Der Schuldner leistet, um dadurch - mit Zustimmung des Gläubigers - auf eine andere als die vorgesehene Weise seiner Verpflichtung nachzukommen, um sich so von seiner Schuld zu befreien"

110. Segundo Larenz, op. cit. (nota 78 supra), p. 248, essa teoria não encontra compatibilidade com o $\$ 365$ do BGB, que trata dos casos de vícios da coisa e da evicção na datio in solutum. Como sabemos, o $\$ 365$ do BGB determina que o devedor, na datio in solutum, deve responder pelos vícios e pela evicção da coisa dada como se fosse um vendedor, não podendo haver o restabelecimento da obrigação primitiva. Desse modo, segundo o autor, o BGB entende que houve uma renúncia por parte do credor da dívida primitiva que é substituída pela nova prestação. Por conseguinte, como a nova prestação extingue a primitiva, uma vez que o credor renuncia a ela, o $\$ 365$ do BGB equipara o credor evicto ao comprador.

111. Cf. nota 78 supra.

112. Op. cit. (nota l supra), pp. 436-438. 
Por conseguinte, alguns autores têm adotado outras soluções quanto a natureza jurídica da dàtio in solutum. Antunes Varela, ${ }^{113}$ v. g., desenvolveu tese própria sobre o tema. $\mathrm{O}$ autor, como explicitamos anteriormente, não-aceita as teses consagradas pela doutrina, relativas à doutrina jurídica da dação em pagamento, uma vez que tais teses não são compatíveis com o ordenamento brasileiro, particularmente o art. 998 do Código Civil. Desse modo, o autor desenvolve sua solução, adequando a natureza jurídica da datio in solutum ao nosso direito vigente.

Assim, o autor busca um conceito em que está presente o aspecto duplo da dação em pagamento no momento único no qual se realiza o ato. Afinal, a datio in solutum é uma ato de solução da obrigação pelo intermédio da substituição da prestação, realizada mediante acordo entre as partes. Desse modo, tal acordo, efetuado no momento da datio, fundamenta tanto a nova prestação efetuada quanto a extinção da obrigação anterior, ambas calcadas na vontade do credor.

Caracteriza-se tal tese de Antunes Varela pelo meio e pelo fim do ato. Para o autor, só teremos a conceituação precisa deste instituto ao considerarmos o meio, que é a realização de uma prestação diversa da original, mediante acordo entre as partes e efetuada no momento da dação, e o fim, que é a extinção da obrigação, determinada pela vontade do credor. ${ }^{114}$

Outros autores ${ }^{115}$ preferiram salientar as características basilares do instituto, não se prendendo a uma categoria preestabelecida.

Desta maneira, temos que o principal efeito da datio in solutum é a extinção de uma relação obrigacional preexistente. Então, a primeira conclusão que

\section{Op. cit. (nota I supra), pp. 208-209.}

114. Não nos parece necessária, contudo, tal elaboração feita pelo autor. Afinal, a discussão em torno da natureza jurídica da datio in solutum, como já explicamos, data desde as divergências entre os sabinianos e os proculianos, não encontrando consenso na doutrina até hoje, que ainda se divide entre as teorias expostas anteriormente (cf. cap. III.2.1.; III.2.2.; e III.2.3.). Desse modo, uma nova teoria não nos parece uma solução para as divergências doutrinárias sobre o assunto, mas apenas uma opção a mais para tal discussão. Além disso, essa construção doutrinária de Antunes Varela baseia-se no fato de, segundo o próprio autor, não haver adequação do art. 998 do Código Civil com as demais teorias sobre a natureza jurídica. Assim, como o art. 998, não é aceito pelos ordenamentos estrangeiros, que defendeın a garantia de evicção análoga à compra e venda, parece-nos, devido a esse pressuposto, uma construção frágil, pois fundamenta-se em uma opção do legislador brasileiro não acolhida pelas codificações estrangeiras.

115. Cf. Rodotà, op. cit. (nota I supra), pp. 737-738; Bianca, op. cit. (nota I supra), pp. 438-439 e Grassetti, Datio in solutum in NNDI cit. (nota 61 supra), p. 174-175 e Datio in solutum in NDI cit. (nota 26 supra), p. 550. 
podemos inferir é tratar-se de um contrato extintivo, ou solutório. ${ }^{116}$ Além disso, cuidase de um contrato oneroso, uma vez que temos a alteração patrimonial de ambas as partes, o devedor dando a coisa em soluto e o credor liberando o devedor da obrigação original. ${ }^{117}$

Temos, ainda, que a datio in solutum é um contrato de formação real, ${ }^{11 \times}$ uma vez que apenas se aperfeiçoará com a traditio da coisa dada em pagamento. ${ }^{119} \mathrm{Ou}$ seja, a obrigação apenas extinguir-se-á, liberando o devedor, quando efetivamente for cumprida a nova prestação. ${ }^{120}$ Tal conseqüência demonstra o caráter real da dação em

116. Assim, Rodotà, op. cit. (nota / supra), pp. 737-738, lembra que para a realização da clatio in solutum, é necessário o. consentimento do credor, uma vez que a dação em pagamento pressupõe a vontade das partes envolvidas, credor e devedor, com intuito de extinguir uma obrigação já existente. Trata-se, desse modo, de um contrato extintivo, já que esse é o principal efeito. O autor ainda lembra que para sua realização, é necessária a existência de uma obrigaçã̀o válida. O autor é acompanhado por Bianca, op. cit. (nota l supra), pp. 438-439, que cita a qualificação da datio in solutum como contrato solutório. Dentre os contratos solutórios, a dação em pagamento caracteriza-se por gerar uma extinção satisfatória do crédito através da efetuação de uma nova prestação, diversa daquela devida. O autor acrescenta que a datio in solutum satisfaz um interesse do credor que substitui aquele interesse primitivo. Por sua vez, Grassetti, Datio in solutum in NNDI cit. (nota 6I supra), p. 174-175 e Datio in solutum in NDI cit. (nota 26 supra), p. 550, também salienta que a datio in solutum é uın contrato liberatório, já que visa ao solvere, à extinção de uma obrigação. Afirma ainda que a datio in solutum é derivada da solutio, podendo-se assim aplicar as normas destinadas ao pagamento em geral.

117. Cf. Rodotà, op. cit. (nota l supra), pp. 737-738. Messineo, op). cit. (nota / supra), p. 273 , corrobora esta tese, definindo nossa figura como um negócio solutório bilateral a título oneroso.

118. Cf. Rodotà, op. cit. (nota I supra), pp. 737-738, Grassetti, Datio in solutum in NNDl cit. (nota 6I supra), p. 174-175 e Datio in solutum in NDI cit. (nota 26 stipra), p. 550, Messineo, op). cit. (nota I supra), p. 273, Colin et Capitant, op. cit. (nota 60 supra), p. 649, Gazzoni, Manuale di diritto privato, 5." ed., Napoli, Edizioni Scientifiche Italiane, 1994, pp. 552-553, e Nicolò, op. cit. (nota 88 supra), p. 249.

119. Rodotà, op. cit. (nota I supra), pp. 737-738, e Grassetti, Datio ill solutum in NNDI cif. (nota 61 supra), p. 174-175 e Datio in solutum in NDI cit. (nota 26 supra), p. 550, acrescentam que a datio in solutum é uın contrato real, mesmo quando o objeto não é um dạre, mas sim uma prestação de fazer ou não fazer ou seja, é um facere ou um non facere, ou ainda mesmo umna transferência de crédito. Assim, a datio in solutum só se aperfeiçoará com a tradição da coisa ou, nestes outros casos, com a execução da prestação nova, uma vez que o simples consenso das partes não basta. No mesmo sentido, Nicolò, opl. cit. (nota 88 supra), p. 250, afirma que a dação em pagamento "non può considerarsi perfetta se non quando il trasferimento si sia effettivamente attuato" Também Crome, op. cit. (nota 21 supra), pp. 262-263, defende que a datio in solutum é um Realgeschäft, devendo ser necessariamente efetiva. Desta maneira, segundo o autor, podemos cogitar uma promissio in solutum.

120. Galgano, Diritto privato, 6." ed., Padova, CEDAM, 1990, p. 193, é bastante claro ao afirmar que o devedor somente liberar-se-á no momento em que a prestação diversa da original for executada e não quando o credor consente em receber tal prestação diversa. 
pagamento. ${ }^{121}$ Dessa forma, lembra Messineo, ${ }^{122}$ sem que haja a transferência do direito de propriedade ou de outro direito, a dação em pagamento não se aperfeiçoa. Essa é a posição dominante na doutrina, apesar de existirem aqueles que a consideram um contrato consensual. ${ }^{123}$

Após tais considerações, podemos concluir que a posição adotada por esses autores que preferiram destacar as características fundamentais de nossa figura jurídica nos parece a mais acertada. Afinal, trata-se de uma postura mais coerente e imune a críticas, tão freqüentes e volumosas, como explicamos nesse capítulo.

\section{Efeitos quanto ao Credor Evicto}

Passemos agora ao exame do tema principal desse trabalho, ou seja, os efeitos da dação em pagamento nos casos do credor evicto.

Essa hipótese é prevista pelo art. 998 do Código Civil, que determina para esses casos o restabelecimento da obrigação primitiva, tornando a quitação dada sem efeito. Além disso, o direito brasileiro, em face do restabelecimento da prestação original, determina o renascimento das garantias e acessórios do crédito, inclusive as garantias prestadas por terceiro, excetuando-se a fiança.

A solução adotada pelo art. 998 afasta-se das consagradas pelos ordenamentos estrangeiros. Na verdade, afasta-se também do próprio art. 996 do Código Civil, que equipara a datio in solutum à compra e venda, ao não aplicar a garantia por eviç̧ão, ${ }^{124}$ tornando-se assim uma exceção ao art. 996 supracitado.

121. Colin et Capitant, op. cit. (nota 60 supra), p. 649, e Huet, op). cit. (uotu 7I supiat), p. 66, lembram que a datio in solutum geralınente visa a transferir um direito de propriedade. Huet acrescenta que, desse modo, nossa figura aproxima-se da compra e venda, que também visa ao efeito translativo da propriedade, tendo assim, 1 : ğ, as mesmas consequiências quanto ao periculum rei venditcie. Vale lembrar que tais considerações da doutrina francesa devem ser examinadas cuidadosamente, umna vez que aproximam a compra e venda da datio in solutum em virtude da peculiaridade do ordenamento francês que classifica esta primeira figura como modo de aquisição de propriedade. Ou seja, na França, o contrato de compra e venda gera a transferência do direito de propriedade, ao contrário, l: gr. do direito brasileiro, em que tal contrato gera apenas obrigações.

\section{Op. cit. (nota I supra), p. 273.}

123. Grassetti, Datio in solutum in NNDI cit. (nota 61 supra), pp. 174-175 e Datio in solutum in NDI cit. (nota 26 supra), p. 550; afirma que parte da doutrina defende tal idéia, ou seja, de que se trataria cle um contrato consensual, posição esta condenada pelo autor. Segundo o autor, tal posição não reconhece a eficácia extintiva e liberatória da datio in solutum, além de impossibilitar a distinção entre o instituto e a compra e venda (ou permuta). Afinal, considerar-se-ia uma compra e venda, a compensação do preço com a prestação primitiva (nos casos de rem pro pecunia), e uma permuta, a troca da coisa dada em soluto no lugar da coisa devida (nos casos de rem pro re), já que não seria necessária a transferência da coisa para a datio in solutum aperfeiçoar-se.

124. Cf. Antunes Varela, op. cit. (nota I supra), p. 205. Também Espínola, op. cit. (nota I supra), p. 77, n. 139; ressalta que os arts. 996 e 998 do Código Civil brasileiro são contraditórios. 
O art. 998 do Código Civil brasileiro consagrou a posição de Marciano e Paulo, ou seja, determina a retomada da obrigação primitiva, como veremos em seguida, enquanto que os ordenamentos estrangeiros abarcaram a tese de Ulpiano, construindo a responsabilidade pela evicção e pelos vícios ${ }^{125}$ nos mesmos moldes da compra e venda. ${ }^{126}$

Esse breve panorama revela o quão controverso apresenta-se o tema desse estudo. As duas posições a respeito desse assunto, presentes nas fontes romanas, dividem a doutrina e separam a legislação brasileira das demais.

\section{Direito Romano: Controvérsia entre Marciano e Ulpiano}

A controvérsia doutrinária e dos códigos sobre os casos de credor evicto na dação em pagamento, como dissemos, remete às soluções totalmente opostas adotadas por Marciano e Ulpiano. Tratemos, primeiramente, do texto de Marciano:

Marci. 3 regularum, D. 46, 3, 46 pr.-1: "Si quis aliam rem pro alia volenti solverit et evicta fuerit res, manet pristina obligatio. Etsi pro parte fuerit evicta, tamen pro solido obligatio durat: nam non accepisset re integra creditor; nisi pro solido eius fieret. 1 . Sed et si duos fundos verbi gratia pro debito dederit, evicto altero fundo remanet integra obligatio. Tunc ergo res pro re soluta liberationem praestat, cum pro solido facta est suscipientis"
Marci. 3 regularum, D. 46, 3, 46 pr.-1: "Se alguém tiver pago alguma coisa no lugar de outra àquele que concedeu e a coisa tiver sido evicta, permanece a antiga obrigação. Ainda que tenha sido evicta em parte, todavia a obrigação permanece pro solido, pois estando integra a coisa, o credor não a teria aceito, a não ser que ela se fizesse dele inteiramente. 1. Mas também, se tiver dado dois terrenos, por exemplo, como pagamento, estando evicto um deles, permanece íntegra a obrigação. Então, portanto, a coisa paga no lugar da coisa libera o devedor, quando integralmente torna propriedade daquele que a recebe".

125. Vale lembrar que também o Esboço de Teixeira de Freitas e o Anteprojeto do Código das Obrigações também preferiram a posição de Ulpiano.

126. Pontes de Miranda, op. cit. (nota I supra), p. I l, também trata das diferenças entre os sistemas jurídicos. Segundo o autor, o direito francês e o italiano revelam resquícios da controvérsia sobre o tratamento dos vícios redibitórios e da eviç̧ão da datio in solutum. Além disso, Pontes de Miranda, op. cit. (nota / supra), pp. 13-14; lembra que o art. 998 só é aplicado para os casos de evicção, restringindo a interpretação de Marciano, uma vez que não abrange os casos de vícios redibitórios. Por conseguinte, o art. 998 consagra a tese de Marciano relativa à evicção, mas não a posição dos proculianos sobre a exceptio doli mali (cf. cap. III.1). 
Assim, o texto apresenta em seu início a datio in solutum nos casos de credor evicto, já que temos o pagamento de uma coisa por outra que se queira e tal coisa torna-se evicta em parte (eviç̧ão parcial). Por conseguinte, temos o cerne do texto de Marciano, que considera a obrigação original conservada por inteiro (manet pristina obligatio), mesmo nos casos de evicção parcial.

Além disso, o $\$ 1$ traz um exemplo de um débito de dois terrenos e apenas um deles torna-se evicto. Mesmo em tais casos, a obrigação inicial permanece inteira. Desse modo, podemos perceber que Marciano defende o restabelecimento da obrigação primitiva para os casos de credor evicto na datio in solutum.

A doutrina tradicional ${ }^{127}$ aponta que este é o mesmo entendimento do seguinte texto de Paulo:

Paul. 15 quaestionum, D. 46, 3, 98 pr.: "Qui res suas obligavit, postea aliquam possessionem ex his pro filia sua dotem promittendo obligavit et solvit. Si ea res a creditore evicta est, dicendum est maritum ex dotis promissione agere posse, ac si statuliberum remve sub condicione legatam dotis nomine pro filia pater solvisset: harum enim rerum solutio non potest nisi ex eventu liberare, scilicet quo. casu certum erit remanere eas."
Paul. 15 quaestionum, D. 46, 3, 98 pr:: "Quem grava seus bens, sucessivamente, prometendo o dote pela sua filha, vincula e paga com uma propriedade que deve ser cumprida. Se a coisa se torna evicta para o credor, diz-se que o marido pode agir com base na promessa de dote, como se, a título de dote pela filha, o pai tivesse pago uma coisa legada sob condição: o pagamento desta coisa, não pode se liberar, a não ser em função do seu êxito, que é neste caso a certeza que permanecerão".

Desse modo, segundo estes autores, em Paul. 15 quaestionum, D. 46, 3, 98 pr. teríamos o restabelecimento da prestação primitiva, uma vez que a ação do credor seria com base na promessa do dote, a dívida original. Entretanto, este não parece ser o entendimento ideal. Assim como Nardi ${ }^{128}$ e Melillo, ${ }^{129}$ entendemos que tal texto não trata de datio in solutum, mas sim de, simplesmente, uma solutio. Não existe o acordo que substitui o objeto da obrigação, característico da dação em pagamento.

127. Cf., dentre outros, Astuti, op. cit. (nota 29 supra), p. 729, Solazzi, op. cit. (nota 2I supra), p. 160, e Zaccaria, op. cit. (nota 1 supra), p. 19, n. 12, que afirmain serem os textos Marci. 3 regularum, D. 46, 3, 46 pr.-I e Paul. 15 quaestionum, D. 46, 3, 98 pr., coincidentes, reservando ao credor evicto contra o devedor uma ação que renasça o crédito originário.

128. Op. cit. (nota 13 supra), p. 63.

129. In solutum dare - contenuto e dottrine negoziali nell'adempimento inesatto, Napoli, Jovene, 1970, pp. 120-122. 
Passemos, então, ao texto de Ulpiano:

Ulp. 30 ad edictum, D. 13, 7, 24 pr:: "Eleganter apud me quaesitum est, si impetrasset creditor a Caesare, ut pignus possideret idque evictum esset, an habeat contrariam pigneraticiam. Et videtur finita esse pignoris obligatio et a contractu recessum. Immo utilis ex empto accommodata est, quemadmodum si pro soluto ei res data fuerit, ut in quantitatem debiti ei satisfiat vel in quantum eius intersit, et compensationem habere potest creditor, si forte pigneraticia vel ex alia causa cum eo agetur."
Ulp. 30 ad edictum, D. 13, 7, 24 pr: "Elegantemente questiona-me se um credor, que houvesse obtido de Caesar poder ter o penhor e este fosse evicto, havia a pignoratícia contrária. Assim, a obrigação apresentar-seia finita e seria recendido o contrato. Ao invés disso, é dada uma utilis ex empto, como se a coisa the fosse dada em pagamento, de modo que seja satisfeito pelo montante do débito ou por quanto do seu interesse, e o credor pode ter a compensação se, por ventura, contra ele tenha-se usado a pignoraticia ou por outra causa"

A questão proposta a Ulpiano, presente em tal texto, trata do caso de um credor de Caesar que se torna evicto por intermédio de um penhor. Assim, reserva-se a esse credor uma actio empti utilis (ou actio utilis ex empto), ou seja, a mesma ação do comprador evicto. A obrigação primitiva é extinta incondicionalmente. Desta maneira, Ulpiano constrói a datio in solutum como uma compra e venda, a que correspondem as mesmas garantias por evicção.

Esta equiparação da dação em pagamento a uma compra e venda também é encontrada no texto de Caracalla:

Ant., C. 8, 44, 4 (de 212 d.C.): "Si praedium tibi pro'soluto datum aliis creditoribus fuerat obligatum, causa pignoris mutata non est. Igitur si hoc iure fuerit evictum, utilis tibi actio contra debitorem competit. Nam eiusmodi contractus vicem venditionis obtinet"
Ant., C. 8, 44, 4 (de 212 d.C.): "Se o terreno dado em pagamento a ti tinha sido gravado em favor de outros credores, a condição do penhor não é alterada. Portanto, se torna-se evicto devido a isto, the é reservada uma actio utilis contra o devedor. Na verdade esse contrato tem o lugar de uma compra e venda"

Estando presentes nas fontes textos de opiniões opostas, a doutrina passou a elaborar diversas soluções que procuram explicar tal divergência.

A primeira solução ${ }^{130}$ para a exegese dos textos pode ser encontrada na

130. Cf. Astuti, op. cit. (nota 29 supra), p. 729, Solazzi, op. cit. (nota 21 supra), pp. 160-161, Allara, op. cit. (nota I supra), p. 252, n. 1, Giorgi, op. cit. (nota 29 supra), p. 390, Zaccaria, op. cit. (nota I supra), p. 19, n. 14, Steiner, op. cit. (nota 45 supra), pp. 50-51, e Ernst, op. cit. (nota 29 supra), pp). 3-4 
Glosa, sendo também adotada por Doneau. ${ }^{131}$ É fundada na distinção entre a datio in solutum quando uma res pro pecunia e quando uma res pro re, ou seja, distinguia-se a dação de uma coisa dada no lugar de dinheiro da dação de uma coisa dada em lugar de outra coisa.

Assim, se o objeto devido primitivamente é uma quantia em dinheiro, a dação de uma coisa passa a ser uma espécie de venda. Desse modo, como a compra e venda, segundo o direito romano, não importa na transferência da propriedade da coisa, o débito deve se considerar extinto apesar da evicção, tendo o credor uma actio empti utilis para o seu ressarcimento. Se, pelo contrário, dá-se no lugar da coisa devida uma outra coisa, temos os elementos da permuta. ${ }^{132}$ Por conseguinte, percebendo-se que a coisa não é de propriedade daquele que a deu, ocorrendo a evicção, demonstra-se que a permuta não é perfeita, permanecendo a primeira obrigação. ${ }^{133}$

A segunda solução ${ }^{134}$ é apresentada por parte da doutrina pandectista,

131. Opera Omnia - commentariorum de Jure civili IV, Florantiae, Clius, 1842, p. 770, n. 12. O autor também equipara a datio in solutum à compra e venda: "Datio in solutum est emptio quac fit brevi manu. Celeritate enim conjugendorum actuum, is actus qui solvendo, et soluto pretii vice reddendo expediendus quasi per occullum intermortums videtur; arg. L. 3. Ultimo de don. int.vir:"

132. Este é o mesmo entendimento de Otto-Schilling-Sintenis, Corpus Juris Civilis in's Deutsche iibersetz.t, v. 4, Leipzig, Carl Focke, 1832, n. 87, que, citando Cuiacio, afirmam ser o texto Marci. 3 regulcurum, D. 46, 3, 46 pr.-1 reservado a permuta: "weil jenes Geben einer anderen Sache glechsam eine permutatio war, und diese ungültig ist, wenn eine fremde Sache gegeben ist"

133. Segundo Astuti, op. cit. (nota 29 supr(t), p. 729 e Solazzi, op. cit. (notu 21 supra), p. 161, tratase de uma distinção gratuita e arbitrária, levando-nos a concluir que a datio in solutum poderia ter una natureza e uma eficácia diversa quando proveniente de uma prestação de coisa ou de uma prestação em dinheiro. Segundo o autor essa prestação deve ser excluída. Além disso, Solazzi lembra que o conceito unitário do instituto foi distorcido sem razão alguma, não tendo qualquer vantagem. Além disso, o direito romano clássico regulava a eviç̧ão do mesmo modo nos casos de compra e venda e nas obrigações de transferência de propriedade. Assim, em ambos os casos o credor não poderia agir antes de sofrer a evicção, sendo a ação sempre aquela referente ao crédito. Conforme tais princípios, o credor que tenha a coisa recebido a coisa em pagamento evicta pode exercer a ação nascida do crédito não satisfeito. Solazzi faz ainda importante observação, acrescentando que essa solução é contrária ao texto de Paulo, em Paul. 15 quaestionum, D. 46, 3, 98 pr., onde o débito primitivo era quase sempre uma soma em dinheiro e onde não era permitido a actio empti, mas sim o credor tem a seu favor o renascimento do crédito antigo. Além disso, Zaccaria, op. cit. (notu / supra), p. 20, n. I4, esclarece que a doutrina considera que tal interpretação dos textos ultrapassa o escrito nas fontes, que não são precisas quanto aos termos utilizados para designar a prestação original. Ou seja, não se pode definir, pelas fontes, se a prestação originária era de coisa ou de dinheiro.

134. Cf. Astuti, op). cit. (nota 29 supr(t), p. 729, Solazzi, op. cit. (nota 21 supra), pp. 162-163, Allara, op. cit. (nota I supra), p. 253 , n. 2, e Steiner, op. cit. (nota 45 supra), pp. 54-58. 
principalmente na figura de Dernburg ${ }^{135}$ e Ernst. $^{136}$ Tal solução tenta superar a dificuldade da conciliação entre os textos, ${ }^{1.37}$ dispondo que os juristas clássicos divergiam sobre a caracterização não só acerca dos efeitos da datio in solutum, mas também sobre a sua natureza jurídica, considerando alguns como uma espécie de pagamento, enquanto outros, pelo contrário, como uma espécie de compra e venda ou permuta.

Por conseguinte, ${ }^{138}$ Marciano e Paulo consideravam a datio in solutum como uma variedade de pagamento, enquanto que Ulpiano tratava-a como um negócio de venda ou permuta. Tais conceituações diversas tem como fundamento funções econômicas diferentes. Desta maneira, Ulpiano defendia que ambas as partes renunciavam a um bem (o credor a um débito e o devedor à coisa dada em pagamento), para adquirir um outro, ao qual atribuíam um valor maior. Já Marciano baseava-se na situação em que o credor, aceitando um acordo, não estava a fazer uma troca, mas, sim, a efetuar uma outra forma de pagamento, uma vez que as condições patrimoniais do devedor não-permitiam, ou pelo menos não-assegurariam mais, a prestação inicialmente devida. ${ }^{139}$

135. Op. cit. (nota 29 supra), pp. 238-240. Dernburg, na verdade, (a despeito da citação de Solazzi, op. cit. (notc 2/ supra), p. 161, e de Astuti, op. cit. (nota 29 supra), p. 729, influenciado pelo primeiro) considera que a solução de Marciano e de Ulpiano são inconciliáveis segundo os princípios. Segundo o mesmo autor, a solução de Marciano baseia-se no condicionamento da extinção da antiga obrigação ao fato do credor poder reter a coisa dada eın pagamento. Já a solução de Ulpiano considera a antiga obrigação incondicionalmente extinta. $\mathrm{O}$ autor lembra, que o entendimento dominante tenta remover essa antinomia, conciliando os textos, apenas por estareın ambas presentes nas compilações justinianéias. Assim, o credor teria a escolha entre unna ou outra ação. Entretanto, o autor considera tal conciliação exterior pouco satisfatória. Desta maneira, Dernburg considera a melhor solução conceder ao credor apenas a garantia por evicção (cf. Cuq, op. cit. (notu 29 supra), p. 520, que também considera a solução de Ulpiano mellhor que a de Marciano: "une solution meilleure fut proposée par Ulpien"). Afinal, a dação em pagamento extinguiu definitivamente, e não condicionalınente, a obrigação primitiva. O autor afirına que a repristinação da relação obrigacional não pode ser fundada na vontade das partes, que a extinguiu sem qualquer reserva. Essa preferência de Dernburg pela garantia por evicção, talvez tenha influenciado a sua consagração pelo $\$ 365$ do BGB, como sugere Ernst, (1). cit. (nota 29 supra), p. 72: "Vielleicht sind diese Bestimmungen unter dem Einfluss der Dernburg'schen Ausführungen getroffen worden”

136. Op. cit. (nota 29 supra), pp. 70-71.

137. Devemos lembrar que os pandectistas tinham sempre o intuito de conciliar as diversas fontes romanas, uma vez que, até o início do século XX, o Corpus luris Civilis era direito vigente na Alemanha. Assim, é preciso analisar cuidadosamente tais soluções.

138. Cf. Solazzi, op. cit. (nota $2 I$ supra), p. 162-163.

139. Solazzi, op. cit. (nota $2 I$ supra), p. 163, critica tal solução, pois considera muito discutível que se possa ou mesmo, seja útil, empreender una pesquisa sobre o ânimo inicial das partes que compõem a datio in solutum. Segundo o autor, não podemos encontrar qualquer vestígio de uma pesquisa em tal sentido feita pelos juristas romanos, uma vez que os textos enunciam as discussões contrastantes, mas não as justificam, nem se referem a conceitos diversos sobre a datio in solutum. 
Solazzi ${ }^{140}$ critica essa interpretação, pois considera-a prejudicada pelo fato de que o mesmo jurista tinha soluções diferentes sobre a razão dessa datio in solutum. O mesmo autor aponta outro texto de Ulpiano:

Ulp. 26 ad edictum, D. 12, 6, 26, 4: "Si centum debens, quasi ducenta deberem, fundum ducentorum solvi, competere repetitionem Marcellus libro vicensimo digestorum scribit et centum menere stipulationem: licet enim placuit rem pro pecunia solutam parere liberationem, tamen si ex falsa debiti quantitate maioris pretii res soluta est, non fit confusio partis rei cum pecunia (nemo enim invitus compellitur ad communionem), sed et condictio integrae rei manet et obligatio incorrupta: ager autem retinebitur, donec debita pecunia solvatur"
Ulp. 26 ad edictum, D. 12, 6, 26, 4: "Se devendo cem, pensa que devesse duzentos e dá em pagamento um terreno de duzentos, Marcellus no livro vinte do Digesto escreve, que compete a repetição, subsistindo a dívida de cem. Assim, pode-se determinar que uma coisa dada em pagamento no lugar de dinheiro, produz a liberação, porém se por erro for dada coisa de preço maior, não há a compensação de parte da coisa com o dinheiro (pois não se obriga contra a sua vontade em comunhão com a do outro), mas permanece a repetição da coisa inteira e a obrigação intacta: o terreno será devolvido até que a divida seja paga"

Assim, se Ulpiano, em Ulp. 30 ad edictum, D. 13, 7, 24 pr., iguala a datio in solutum à compra e venda, ao passo que, em Ulp. 26 ad edictum, D. 12, 6, 26, 4 , enuncia uma decisão que não é compatível com tal equiparação à venda. ${ }^{141}$ Teın-se o caso que um devedor de uma quantia de cem faz a datio in solutum com uma propriedade que valha duzentos, transformando-se por erro em um devedor de duzentos. Desse modo, se a datio in solutum fosse concebida análoga a venda, percebendo-se que o devedor teria vendido ao credor a propriedade por duzentos, haveria a compensação do preço com o débito, pois assim identificar-se-ia a dívida da quantia de cem e reconhecer-se-ia ao devedor o direito de se repetir os outros cem. De qualquer forma, entretanto, a propriedade deveria permanecer com o credor. Ulpiano, pelo contrário, decide que o antigo crédito de cem perdura e o devedor teria possibilidade de ser restituído na propriedade, não mantendo assim, em Ulp. 26 ad edictum, D. 12, 6, 26,4 , a equiparação à compra e venda feita em Ulp. 30 ad edictum, D. 13, 7, 24 pr. ${ }^{142}$

140. Op. cit. (nota 21 supra), p. 163.

141. Solazzi, op. cit. (nota 21 supra), p. 163.

142. Ainda segundo Solazzi, op. cit. (nota 21 supra), p. 163, Paulo também apresenta soluçōes controversas. Em Paul. 15 quacstiomum, D. 46, 3, 98 pr., declararia que se a coisa dada em pagamento se torna evicta, permanece a antiga obrigação ("dicendum est maritum ex dotis promissionle agere"). Entretanto, o mesmo jurista em Paul. 54 ad edictum, D. 41, 3, 4, 17, equipara a datios in solutum à perınuta, 
Karlowa ${ }^{143}$ e Kretschmar ${ }^{144}$ apontam uma terceira solução, ${ }^{145}$ que busca conciliar a antinomia das decisões concernentes à evicção da coisa dada em pagamento, baseando-se na controvérsia entre os sabinianos e proculianos sobre a eficácia liberatória da datio in solutum. Segundo os proculianos, em caso de evicção, a obrigação originária deveria conservar-se completa, excluindo a oponibilidade da exceptio doli ao credor evicto. Já entre os sabinianos, como a obrigação estaria extinta ipso iure pela datio in solutum, era coerente atribuir ao credor uma actio empti utilis contra o devedor. 146

Tal opinião foi bastante criticada. Primeiramente, Solazzi ${ }^{147}$ defende que as divergências entre os sabinianos e proculianos não alterariam os efeitos da datio in

nāo restabelecendo a obrigação primitiva. Melillo, (o). cit. (notı 134 supra), p. 96, diferenteınente da communis opinio, entende que Ulpiano, em Ulp. 26 ad edictum, D. 12, 6, 26, 4, não retoma a prestação primitiva devido a falta da transferência do domínio no negócio. Mas sim, a vontade foi viciada, sem efeito translativo. Já em Paul. 54 ad edictum, D. 41, 3, 4, 17, Melillo, op. cit. (nota /29 supra), pp. 120122, entende não se tratar de um texto de datio in solutum.

143. Römische Rechtsgeschichte. II-I. Privatrecht, Leipzig, Veit \& Comp., 1901, p. 1382.

144. Die Erfiillung I, Leipzig, Veit \& Comp., 1906.

145. Cf. Astuti, op. cit. (nota 29 supra), pp. 729-730, Solazzi, op). cit. (nota 45 supra), pp. 161-162, Allara, op). cit. (nota l supra), p. 253, n. 4, e Steiner, op. cit. (nota 21 supra), pp). 58-59.

146. Essa é a solıção defendida por Pontes cle Miranda, op. cit. (notı / sıpra), p. 20. Desse modo, observa o autor, como Marciano era um proculiano, defendia a retomada da prestação original da dívida, pois, repita-se, por ser proculiano, acreditava não produzir a datio in solıtum uma extinção ipso iurc a obrigação. Já Ulpiano, ainda segundo o mesıno autor, justamente por ser um sabiniano, conferia ao credor a garantia por evicção como se fosse um comprador evicto, uma vez que, para ele a dação em pagamento era um modo de extinção ipso iutre da obrigação, não tendo sentido o renascimento da prestação original, já extinta. Tal opinião de Pontes de Miranda revela o quão complicada é a solução adotada pelo direito brasileiro. Ao se privilegiar a solução de Marciano quanto aos casos de credor evicto, fez-se necessário abrir uma exceção à regra geral da extinção ipso iure da dívida, efetuada pela dação em pagamento, uma vez que, obviamente, não se pode falar em extinção ipso iurc com restabelecimento da prestação primitiva. Sohm-Mitteis-Wenger, lnstitutionen - Geschichte unss System des römischen Privatrechts, 17." ed., München und Leipzig, Duncker \& Humblot, 1923, p. 480, também concordam com a solução de Karlowa, op. cit. (notı 198 supra), p. 1382, e Kretschmar, op. cit. (nota 199 sıpra), uma vez que nos casos de eviç̧ão na dario in solutum, afirma que os proculianos a consideravam nula, podendo o credor reviver o antigo crédito, até mesıno sobre a coisa penhorada e contra o fiador. $O$ autor cita o texto de Marciano como fonte de tal solução. Já segundo os sabinianos, a datio in solutum não seria inválida, tendo o credor, entretanto, a mesma ação de garantia da compra e venda contra o devedor, citando, o autor, o texto de Ulpiano.

147. Op. cit. (nota 21 supra), p. 162. 
solutum nos casos de evicção. ${ }^{148}$ Já Musumeci ${ }^{149}$ vai além, criticando o posicionamento de Solazzi e demonstrando que Marciano não classificava a dação em pagamento como modo ope exceptionis, como os proculianos, mas sim como extinção ipso iure, do mesmo modo que os sabinianos. ${ }^{150}$

Ferrini ${ }^{151}$ também apresenta uma tese própria sobre os textos de Marciano e Ulpiano, a nossa quarta solução. ${ }^{152} \mathrm{O}$ autor considera a datio in solutum como uma verdadeira forma de pagamento, regida pelo princípio de que se a obrigação consiste em um dare e o credor torna-se evicto, não tendo a propriedade da coisa recebida, "manet pristina obligatio", ou seja, renasce a obrigação primitiva. Entretanto, o credor seria equiparado ao comprador, concedendo-se a ele uma actio empti utilis, nos casos em que a datio in solutum seja "pro debito", considerado o domínio da coisa pignoratícia. ${ }^{153}$

A nossa quinta solução é a defendida pela doutrina pandectista tradicional, como informa Astuti. ${ }^{154}$ Trata-se da coexistência entre as duas ações em concurso eletivo.

148. Solazzi, op. cit. (nota 21 supra), p. 162, nega, inclusive, a controvérsia, neste ponto, entre sabinianos e proculianos. Para os sabinianos, que atribuíam a datio in solutum a mesma eficácia dada à solutio, seria impossível a evicção ter na datio in solutum efeitos diversos daqueles produzidos na solutio. Assim, se na solutio a eviç̧ão invalida o pagamento e permite subsistir a obrigação que com o pagamento se pretende extinguir, na datio in solutum a evicção não poderia considerar a obrigação primitiva extinta. Além disso, tanto os sabinianos como os proculianos, tratando da datio in solutum, consideram o termo dare como transmissão da propriedade. Desse modo, as duas escolas devem estar coincidentes que não existe uma datio in solutum onde o devedor não é liberado, nem ipso iure, nem ope exceptionem, se o credor não adquire a propriedade da coisa recebida em pagamento.

149. Op. cit. (nota 29 supra), pp. 525-538.

150. Musumeci, op. cit. (nota 29 supra), p. 528, afirma que as diversas fattispecie previstas em Marci. 3 regularum, D. 46, 3, 46 pr.-2, revelaın uın único princípio. Ou seja, se o credor obtém ınenos ou não obtém aquilo que tinha aceitado, a datio in solutum não produz qualquer efeito, uma vez que não satisfez o credor. Aléın disso, o mesıno autor entende que a expressão manet pristina obligatio é sabiniana, já que o efeito normal da datio in solutum seria, para eles, o da extinção ipso iure. Ainda, Musumeci defende que o verbo liberare, presente no texto de Marciano, "ergo res pro re solutu liberationem praestu". era usado apenas para as extinções ipso iure.

151. Manuale di Pandette, Milano, Società Editrice Libraria; 1900, p. 626, n. 3.

152. Cf. Astuti, op. cit. (nota 29 supra), p. 730, e Solazzi, op. cit. (nota 34 supra), p. 163.

153. Solazzi, op. cit.(nota 21 supra), p. 163, entretanto, afirma que as fontes não apresentam nenhuma prova que confirme a solução de Ferrini, op. cit. (nota 151 supra), p. 626, n. 3. Além disso, o mesmo autor afirma que o texto de Ulp. 30 ad edictum, D. 13, 7, 24 pr..não faz qualquer alusão ao penhor. Além disso, se o texto $A$ ilt., C. 8, 44, 4 (de 212 d. C.) supõe que o credor tenha recebido em pagamento um terreno "aliis creditoribus obligatum", não diz que o destinatário tivesse também um direito de penhor sobre o terreno e, ainda, que este seria considerado "pro debito".

154. Op. cit. (nota 29 supra), p. 730. Cf. também Allara, op. cit. (nota / supra), p. 252, n. 3, Giorgi, op. cit. (notu 29 supra), pp. 390-391, e Steiner, op. cit. (nota 45 supra), pp. 59-60. 
É a defendida por, dentre outros, Windscheid, ${ }^{155}$ que considera, nos casos de evicção total ou parcial, o direito do credor de escolha entre o retorno ao seu antigo crédito e a exigência da garantia por evicção.

Ainda segundo Windscheid, ${ }^{156}$ o primeira ação do credor, encontrada no texto de Marciano, baseia-se no adimplemento da tradição com efeito de transmissão de propriedade (e não da tradição como tal). Já a segunda ação, consagrada por Ulpiano, é atribuída ao vínculo do devedor em transmitir a propriedade da coisa ao credor, presente em sua declaração. ${ }^{157}$

A sexta solução é proposta por aqueles que defendem o cúmulo das duas ações até o ressarcimento total do prejuízo advindo da evicção. ${ }^{15 x}$ Dentre tais autores, Glück ${ }^{159}$ explica que ao considerar a obrigação primitiva como não-extinta pela datio in solutum, nos casos em que a transmissão da propriedade da coisa dada em pagamento permite que haja uma evicção (v. g., nos casos de hipoteca), o credor teria o direito de permanecer com o seu crédito, inclusive com as garantias de penhor.

Segundo o mesmo autor, tal solução concede ao credor a vantagem de poder agir contra o devedor, através da obrigação primitiva, sem que seja necessário sofrer evicção. Além disso, caso esta ocorra, o credor terá a sua disposição a actio empti utilis, ou seja, a garantia por evicção.

A sétima solução é apresentada por Giorgi, ${ }^{160}$ que corrobora aquela proposta por Favre. ${ }^{161}$ Baseia-se na distinção entre a ação pessoal, que quando extinta não mais revive, mesmo com a eviç̧ão, e a ação hipotecária, que não se extingue nos casos de credor evicto.

155. Op. cit. (nota 29 supra), p. 317.

156. Op. cit. (nota 29 supra), p. 317, n. 14.

157. Para Astuti, op. cit. (nota 29 supra), p. 730, tal solução ê contraditória, uma vez que a ação que promove o restabelecimento da prestação primitiva pressupõe a sobrevivência da obrigação, enquanto que a actio empti utilis pressupõe a extinção da mesma obrigação, não importando a evicção. Allara, op). cit. (nota l supra), p. 252, n. 3, também critica o entendimento da pandectística tradicional, não considerando que está suficientemente claro nas fontes. Cf. também nota 133 supra e Dernburg, op) cit. (nota 29 supral), pp. 239-240.

158. Cf. Allara, op. cit. (nota I supra), p. 252, n. 4.

159. Glück, Ausführliche Erläuterung der Pandecten XVI, Erlangen, Palın \& Enfe., 1868 (trad. it. de Silvio Perozzi e Pietro Bonfante, Commentario alle Pandette XXI, Milano, Società Editrice Libraria, 1898, p. 149).

160. Op. cit. (nota 29 supra), pp. 391-392.

161. Rationalia in tertiam partem Pandectarum III.J, Lugduni, Petri Borde \& Guilielmi Barbier, 1663, pp. 641-643. Seugndo o autor, quando a actio pignoraticia contraria for incompatível, manct pristina obligatio, ou seja, renasce a prestação primitiva. Caso contrário, aplica-se o texto de Ulpiano. 
Assim, segundo o mesmo autor, se a coisa dada em pagamento é reivindicada por um terceiro, que demonstra não ser o devedor o verdadeiro proprietário da coisa, aplica-se a solução de Marciano, ou seja, desconsidera-se a datio in solutum, repristinando a obrigação primitiva. Entretanto, se a evicção é baseada em uma ação hipotecária de um outro credor, deve privilegiar-se o texto de Ulpiano, extinguindo-se a antiga obrigação e reservando ao credor evicto a actio empti utilis. ${ }^{1 / 2}$

A oitava e última solução é defendida por Allara, ${ }^{163}$ que tem uma tese própria para a exegese dos textos de Marciano e Ulpiano, apesar de reconhecer a dificuldade ou até mesmo a impossibilidade de uma solução ideal. Assim, o autor defende que a divergência entre os dois grupos de fragmentos decorre da proveniência de ordenamentos diversos das soluções adotadas por Marciano e Ulpiano.

Desta maneira, segundo o ius civile, a obrigação primitiva deve ser restabelecida quando não há a transferência de propriedade da coisa dada em soluto, não sendo suficiente a simples traditio. Tal solução, como sabemos, é a presente no texto de Marciano, devendo, assim, "manet pristina obligatio." Entretanto, o ius honorarium reserva ao credor evicto a actio empti utilis, visando à melhor defesa do interesse do mesmo, prevista por Ulpiano.

Além destas soluções, vale lembrar que a doutrina, ${ }^{164}$ acompanhando a tese de De Francisci, ${ }^{16.5}$ afirma ser a equiparação do credor evicto da datio in solutum

162. Giorgi, op. cit. (not، 29 supra), p. 392, defendendo tal solução, afirma que se esta não for a interpretação exata dos textos de Marciano e Ulpiano, já que provavelmente são inconciliáveis por pertencerem a escolas contrárias, certamente atendem a justiça e os princípios gerais do direito.

163. Op. cit. (nota I supra), p. 254.

164. Cf. Kaser, Das römische Privatrecht I cit. (nota 29 supra), p. 638, Bonfante, op. cit. (nota 29 supra), p. 423, n. I, Arangio-Ruiz, op. cit. (nota 13 supra), p. 394, Monier, op. cit. (nota 29 supra), p. 220, Perozzi, op. cit. (nota 29 supra), p. 416, n. 2, Biondi, (nota 29 supra), pp. 158-159, Steiner, op. cit. (nota 45 supra), p. 75 , Weiss, (nota 29 supra), p. 435 , e Musumeci, op. cit. (nota 29 supra), p. 527 , n.9.

165. La dottrina bizantina cit. (nota 44 supra), p. 302 e Suum cuique tribuere in BIDR 27 (1914), pp. 31]-312. Neste último texto, De Francisci explica que sua conclusã̉o, a de que os textos eram interpolados, até então considerada inédita pelo autor, na verdade, já tinha sido proposta por Rabel, Die Haftung des Verkäufers - wegen mangels im Rechte. I. Geschichtliche Studien ïber den Haftungserfolg, Leipzig, Veit \& Comp., 1902, pp. 113-114, Joze anos antes. Até os argumentos, revela De Francisci, Suum cuique cit. (nesta nota), p. 311 , são os mesmos. Tais explicações são corroboradas por Rabel, Grundzüge des rïmischen Privatrechts, 2." ed., Basel, Benno Schwabe \& Co., 1955, pp. 144-145: "Der Schuldner haftet wegen Eviktion mit einer Klage, die die Kompilation der actio empti analog setzt [Ant., C. 8, 44, 4 (de 212 d.C.)], sicher nach Marcian D. 46, 3, 46 pr. aus der alten Obligation”. Cabe lembrar que, erroneamente, Kaser, Das rïmische Privatrecht I cit. (nota 29 supra), p. 638, n. 33, cita Rabel, Die Haftung cit. (nesta nota), p. I13, como um dos autores que considera tais textos autênticos. 
ao comprador, trazida pelos textos Ulp. 30 ad edictum, D. 13, 7, 24 pr., e Ant., C. 8, 44, 4 (de 212 d. C.), uma construção dos compiladores, sendo interpolados exatamente na parte divergente em relação ao texto de Marciano, Marci. 3 regularum, D. 46, 3, 46 pr.1, que consagra o princípio clássico do renascimento da prestação primitiva. Entretanto, isoladamente, Melillo, ${ }^{166}$ entende que a analogia da dação em pagamento com a compra e venda é clássica.

Desse modo, Ant., C. 8, 44, 4 (de 212 d.C.), segundo estes autores, ${ }^{167}$ apresenta diversas evidências de interpolação. ${ }^{168}$ Primeiramente, tal texto considera a dação em pagamento um contractus. Os clássicos não utilizavam o termo "contrato" para uma figura que tem como objetivo extinguir uma obrigação.

Outra indicação está nos verbos fuerat e fuerit. Entende-se que o fato do terreno dado em pagamento estar sujeito a um penhor é certo e acabado (fuerat), enquanto que a evicção seria uma hipótese (fuerit). Assim, o primeiro seria uma fato relatado e o segundo uma suposição do imperador, o que seria bastante improvável, já que o imperador não daria conselhos sobre fatos não denunciados. Quanto aos aspectos formais, os termos igitur, utilis actio competit, hoc iure, eiusmodi, revelam o estilo dos compiladores. ${ }^{1\left({ }^{6}\right)}$

Já segundo Melillo, ${ }^{170}$ os críticos não conseguem demonstrar alterações substanciais, devendo ser autêntico o texto. Outro motivo, que serve de argumento contra a opinião interpolacionista, é que em Dio. et. Max., C. 7, 45, 8 (de 283 d.C.), temos o restabelecimento da prestação primitiva na dação em pagamento. Desta maneira, enfraquece-se a explicação de que era uma tendência justinianéia a concessão da actio utilis ex empto. ${ }^{171}$

166. Op. cit. (nota 129 supra), pp. 131-132.

167. Cf. notas 164 e 16.5 supra.

168. Cf. Solazzi, op. cit. (nota 21 supra), pp. 166-167.

169. Solazzi, op. cit. (nota 21 supra), p. 167, explica que a utilização do termo igitur antes de uma preposição era uma característica compilatória. Já utilis actio competit não era linguagem clássica, uma vez que em tal época empregavam o verbo competere apenas para as ações diretas e datur para actio utilis. Nardi, op. cit. (nota 13 supra), pp. 95-96, n. 84, acrescenta que todo final do texto, que equipara claramente a datio in solutum à compra e venda, nam eiusmodi contractus vicem venditionis obtinet, é interpolado.

170. Op. cit. (nota 129 supra), pp. 112-116.

171. Melillo, op. cit. (nota 129 supra), pp. 117-119, considera ainda que o texto Dio. et. Max., C. 7, 45,8 (de 283 d.C.) apresenta traços de intervenção justinianéia, uma vez que era improvável que a chancelaria respondesse a dois quesitos simultaneamente, a compra e venda e a datio in solutum: "Sono perciò riconoscibili nel rescritto due mani; quella, genuina, riferentesi alla compravendita, e quella, spuria, riferentesi alla prestazione sostitutiva". De Francisci, La dottrina bizantina cit. (nota 44 supra), p. 308, 
Também o texto Ulp. 30 ad edictum, D. 13, 7, 24 pr. demonstra ter sido interpolado. ${ }^{172}$ Tal excerto tratava da fiducia, uma vez que o livro 30 ad edictum de Ulpiano era dedicado a esta figura. Além disso, ut possideret remete ao direito do credor fiduciário de obter a posse da coisa, já que tinha a propriedade.

Por conseguinte, a questão apresentada a Ulpiano era se o credor tinha a actio fiduciae contraria, contra o fiduciante, se a evicção tivesse ocorrido depois da impetratio possessionis. Se tal credor torna-se evicto, pelo verdadeiro proprietário, antes da impetratio possessionis, não há dúvidas que poderia utilizar a actio fiduciae contraria. Entretanto, quando pediu ao imperador a posse do objeto da fidúcia, o credor é retirado do contrato, tendo a permissão para defender-se da evicção. Desse modo, Ulpiano negaria a actio fiduciae contraria contra o devedor ou qualquer outro. ${ }^{173}$

Portanto, ainda segundo Solazzi, ${ }^{174}$ o texto Ulp. 30 ad edictum, D. 13, 7 , 24 pr. não trata da ação referente ao crédito, mas sim da ação relativa à fidúcia ou ao penhor. A ação do crédito continuava a disposição do credor, uma vez que o devedor não estava liberado de pleno direito, mas apenas através de uma exceção, que lhe falta com a evicção da coisa. Ademais; os compiladores não teriam compreendido tal situação, confundindo a ação de obrigação principal com a da garantia, entendendo que negada a actio fiduciae contraria, estar-se-ia refutando qualquer ação. ${ }^{175}$

Ainda, vale lembrar que esta crítica interpolacionista não deve ser considerada tão relevante. Mesmo aceitando, o que nos parece bastante razoável, que

um dos percursores da crítica interpolacionista não consegue explicar o conteúdo de Dio. et. Max., C. 7 , 45, 8 (de 283 d.C.), limitando-se a comentar ser tal texto contrário a tendência de equiparar a datio in solutum à compra e venda.

172. Cf. Solazzi, op. cit. (nota 21 supra), pp. 168-169. Já Nardi, op. cit. (nota 13 supra), p. 116, n. 108, considera a primeira parte do texto, que trata do penhor, autêntica. Além disso, o mesmo autor, op. cit. (nota / 3 supra), pp. 116-117, n. 109, afirma não ser interpolado o trecho et videtur finita esse pignori.s obligatio et a contractu recessum. Ainda, Nardi, op. cit. (nota 13 supra), pp. 119-120, n. 111, entende ser interpolado o final do texto, et compensationem habere potest creditor, si forte pigneraticia vel ex alia causa cum eo agetur:

173. Cf. Solazzi, op. cit. (nota 21 supra), p. 168.

174. Op. cit. (nota 21 supra), pp. 168-169.

175. O mesmo Solazzi, op. cit. (nota 21 supra), p. 169, acrescenta que a interpolação é certa por outros fatores. Para o autor, a "elegância" da questão estava no pedido de uma actio fiduciue, Já que não seria elegante o restabelecimento da ação pessoal do crédito. Ainda, é estranha a solução de Ulpiano quanto ao resultado da ação, prevendo ut in quantitatem debiti ei satisfiat vel in quantum eius intersit, ou seja, de modo que seja satisfeito pelo montante do débito ou por quanto do seu interesse. Na verdade, a actio utilis ex empto só adınite como objeto o prejuízo causado pela evicção, portanto, quantum cius intersit. 
o princípio clássico seria o do restabelecimento da prestação primitiva, presente em Marci. 3 regularum, D. 46, 3, 46 pr.-1, é inegável a importância dos textos Ulp. 30 ad edictum, D. 13, 7, 24 pr. e Ant., C. 8, 44, 4 (de 212 d.C.).

Assim, entendemos as interpretações dadas pela grande maioria dos autores, tentando a conciliação dos textos de Marciano e Ulpiano devem ser encaradas com certa reserva. A nosso ver, não há qualquer elemento fundamental que permita aceitar como correta qualquer uma das soluções apresentadas. Desse modo, é preciso analisar os textos de Marciano e Ulpiano separadamente, como tratamentos diversos para a mesma matéria. Afinal, os próprios autores admitem a enorme dificuldade de uma interpretação correta. ${ }^{176}$

\section{Direito Moderno: diversas soluções}

Diante da controvérsia exposta, os legisladores e a doutrina moderna divergem sobre a melhor solução para os casos de credor evicto na datio in solutum. Segundo Allara, ${ }^{177}$ podemos identificar cinco diferentes teses para tais casos, sendo a seguir analisadas.

\subsection{Retomada da prestação ${ }^{178}$ original}

O controverso assunto da evicção na datio in solutum apresenta como uma de suas soluções a retomada da prestação original da obrigação. Essa era, como já explicitamos, a solução de Marciano no direito romano.

Como sabemos, essa foi a solução adotada pelo Código Civil brasileiro, que em seu art. 998 determina o "restabelecimento da obrigação primitiva" gerando também os renascimentos das garantias e dos acessórios da obrigação, inclusive as garantias provenientes de terceiros, com exceção da fiança.

176. Cf. Giorgi, op. cit. (nota 29 supra), p. 392, e Allara, op. cit. (nota I supra), p. 254.

177. Op. cit. (nota 1 supra), pp. 255-258.

178. A utilização do termo prestação original (ou primitiva) neste estudo no lugar de obrigação primitiva, consagrado pelo art. 998, é justificada pela análise da natureza jurídica da datio in solutum (cf. cap. III). Afinal, se privilegiarmos a tese da modalidade de pagamento (cf. cap. III.2.3.), não podemos falar em retomada da obrigaçāo primitiva, já que temos apenas uma obrigação em sentido estrito. Por outro lado, se privilegiarmos a tese da novação (cf. cap. III.2.2.), temos duas obrigações em sentido estrito, aquela extinta pela datio in solutum e a outra gerada pela mesma, podendo ser utilizada a expressão obrigação primitiva. Por conseguinte, ao demostrarmos nossa solução para a natureza jurídica da dação em pagamento (cf. cap. III.2.4.), entendemos que a tese da novação não pode ser priorizada, devendo-se utilizar o termo prestação primitiva. Além disso, já vimos que a tese da novação não pode ser considerada em relação ao Código Civil brasileiro, o que nos leva a concluir que o termo obrigação primitiva, trazido pelo art. 998 não possui o rigor necessário. 
Espínola ${ }^{179}$ lembra que essa solução é repelida pelos ordenamentos estrangeiros, uma vez que, v. g., os doutrinadores italianos e franceses, em sua maioria, consagram a teoria da teoria da novação para a natureza jurídica da datio in solutum, o que inviabiliza a retomada da prestação primitiva. ${ }^{180}$

Beviláqua, ${ }^{181}$ sem maiores explicações, adotou a solução de Marciano em nosso Código Civil, pois considerava esta "mais razoável e mais justa" $1 \times 2$ justificando essa decisão citando ${ }^{1 \times 3}$ Carvalho de Mendonça, ${ }^{184}$ apesar de admitir ser a solução adotada pelo art. 998 do Código Civil brasileiro oposta à adotada pelos códigos e doutrinas estrangeiros, considera-a a melhor solução, lembrando ainda ser aquela que melhor se adapta ao direito brasileiro.

$\mathrm{O}$ autor defende a solução de Marciano pois, como considera a datio in solutum uma modalidade de pagamento, entende que o devedor só se libertará da obrigação se satisfazer aos anseios do credor. Assim, segundo Carvalho de Mendonça, ${ }^{1 \times 5}$ como o credor foi vencido na evicção, logicamente não teve seu crédito satisfeito, o que não-permite a exoneração do devedor. Por conseguinte, o credor deve ter o direito de retomar a prestação original, "se aquela que a substituiu veio a ser anulada' ${ }^{160}$ por fato do devedor" 187 mesmo tendo recebido uma prestação que difere da original, ou ainda, justamente por ter assim recebido. Além disso, justifica o autor, a venda de coisa alheia é "nula" $1 \nless x$ no Direito brasileiro, diferindo da legislação romana, o que nos

179. Op. cit. (nota I supra), p. 74, n. 134.

180. O próprio autor (cf. op. cit. (nota I supra), p. 74, n. I34) privilegia a outra solução para os casos de credor evicto, ou seja, as garantias por eviç̧ão como se o credor fosse um comprador evicto, solução de Ulpiano que explicamos no item seguinte.

181. Op. cit. (nota I supra), p. 147.

182. Op. cit. (nota I supra), p. 147.

183. Código Civil dos Estados Unidos do Brasil (comentado), v. 4, Rio de Janeiro, Livraria Francisco Alves, 1917, p. 156.

184. Op. cit. (nota I supra), pp. 584-587.

185. Op. cit. (nota I supra), pp. 584-587.

186. Vale lembrar que essa construção de Carvalho de Mendonça, op. cit. (nota l supra), p. 587, baseia-se na anulação da datio in solutum por causa da dação de coisa alheia, que resultaria na evicção. Entretanto, como já salientamos, os casos de eviç̧ão não se confundem com anulação.

187. Op. cit. (nota I supra), p. 587.

188. Novamente Carvalho de Mendonça, op. cit. (notu / supra), p. 587, não-emprega corretamente o conceito de anulaçäo. Tanto o autor como Beviláqua, op. cit. (notu / supra), consideram a venda de coisa alheia, venda a non domino, "nulas" no Direito brasileiro. Admitem, entretanto, que tais figuras podem ser convalidadas pela posterior aquisição da coisa pelo vendedor. Na verdade, não se trata de uma venda inválida, já que não estamos no plano da validade. Trata-se de uma venda ineficaz (plano da eficácia), que pode tornar-se eficaz com a aquisição da coisa vendida. 
leva a concluir que também a dação de coisa alheia é inválida, o que conduziria a sua anulação ${ }^{184}$ e o conseqüente renascimento da prestação primitiva.

Allara ${ }^{10(0}$ afirma que essa primeira solução baseia-se no fato da prestação efetuada pelo devedor ter o lugar do adimplemento pela comum vontade das partes, não havendo nos casos de credor evicto qualquer satisfação do mesmo e, conseqüentemente, a não-extinção da obrigação. Além disso, segundo o autor, para os defensores dessa solução, a datio in solutum é um contrato real-extintivo, em que a simples tradição material não é suficiente para a produção de qualquer efeito jurídico. ${ }^{\mid 9 !}$

Por conseguinte, nesta tese, com a evicção da coisa dada em pagamento, e mesmo antes da sua ocorrência, não se tem a extinção da relação obrigacional. Assim, é preciso o caráter de definitivo para que se tenha o adimplemento, ou seja, não-basta a simples entrega da posse, fazendo-se necessária a transmissão da propriedade. ${ }^{192}$

Ainda segundo Allara, ${ }^{193}$ tal característica dessa solução impossibilita uma posterior convalidação da datio in solutum de coisa alheia e a conseqüente extinção da relação obrigacional, nos casos, $v . g$., de aquisição posterior da coisa por parte do devedor. ${ }^{194}$

A última observação do autor é, a nosso ver, o principal problema dessa solução: não temos a total proteção do credor, uma vez que não há na ação de retomada do crédito primitivo uma completa indenização de seu prejuízo. ${ }^{195}$ Zaccaria $^{1 \%}$ acrescenta

189. Cf. notas 186 supra e 188 supra.

190. Op. cit. (nota l supra), p. 259.

191. Giorgi, op. cit. (nota 29 supra), p. 385, tratando dos casos mais comuns de datio in solutum, ou seja, os de rem pro re e rem pro pecunia, afirma ser necessária a transferência de propriedade da coisa para tais casos em que ocorre a entrega de uma coisa. Lembra, ainda, que se for de conhecimento das partes, é válida a datio in solutum de coisa alheia, ressalvados os direitos do verdadeiro proprietário.

192. Allara, op. cit. (nota I supra), p. 259, lembra, entretanto, que a não-ocorrência da transmissāo da propriedade não leva a inexistência de qualquer negócio jurídico entre as partes, podendo gerar outros efeitos. Assim, $v . g$., pode o credor de boa-fé, eventualmente, gozar dos frutos da coisa dada em soluto até que sofra evicção. Contudo, o autor indaga se tal enriquecimento do credor seria compatível com a ação que restabelece o crédito primitivo. A nosso ver, tal observação do autor é bastante pertinente, uma vez que tal solução limita-se a retomar a prestação inicial. Desse modo, teríamos a necessidade de outra ação relativa, $v . g$., aos frutos da coisa.

193. Op. cit. (nota l supra), p. 259.

194. O autor também afirma que provavelmente os defensores dessa tese não previram tais hipóteses, não aplicando essa solução em tais casos.

195. Ainda segundo Allara, op. cit. (nota I supra), p. 259, o credor poderia fazer valer a sua indenização provando uma culpa in contrahendo do devedor, tendo, entretanto, o ônus da prova e a limitação do ressarcimento ao valor do seu interesse negativo.

196. Op. cit. (nota 1 supra), p. 261. 
que além do restabelecimento da prestação primitiva, o credor evicto poderá pleitear o ressarcimento dos seus danos, com base nas normas de inadimplemento. ${ }^{197}$

Zaccaria $^{10 \times}$ ainda questiona se a retomada da prestação originária, que leva à resolução da dação em pagamento, deve ser obtida pelo credor por meio de uma demanda judicial ou pela sua simples manifestação de vontade, exigindo o adimplemento da prestação primitiva. Segundo o autor, não é necessária uma demanda judicial, sendo atribuída ao credor a possibilidade de exigir diretamente. ${ }^{19 \%}$

\subsection{Garantia do comprador evicto}

Outra solução possível para os casos de évicto na datio in solutum é a de Ulpiano, ou seja, a aplicação da garantia por evicção como se fosse um contrato de compra e venda. Conforme já dissemos, é a solução adotada pelo Direito estrangeiro ${ }^{2(x)}$ e completamente contrária à apresentada no item anterior. ${ }^{201}$

Tal posição é adotada pelo $§ 365$ do $\mathrm{BGB},{ }^{202}$ ao estabelecer que se uma

197. Zaccaria, op. cit. (nota / supra), p. 261, afirma ainda que tal ressarcimento do credor abrangerá os danos sofridos por não poder dispor da prestação devida. Ou seja, trata-se do mesıno ressarcimento quanto ao devedor constituído em mora.

198. Op. cit. (nota I supra), p. 259.

199. Zaccaria, op. cit. (nola / supra), p. 259, lembra que a ratio da norma que possibilita a retomada da prestação original nos casos de evicção na datio in solutum (no caso, o art. 1.197, 11 e llI do Código Civil italiano) é a proteção do interesse do credor frente a ampla possibilidade do devedor de liberar-se da obrigação pela datio in solutum. Segundo o mesıno autor, esta ratio não é condizente com a necessidade de uma demanda judicial.

200. Além do $\$ 365$ do BGB, Pontes de Miranda, op. cit. (nota / supra), p. 20, e Fontes e Evolusão do Direito Civil Brasileiro, Rio de Janeiro, Pimenta de Mello \& C., 1928, pp. 247-248, lembra que a solução de Ulpiano foi consagrada pelo art. 2.038 do Código Civil francês. Também o art. 783 do Código Civil argentino e o art. 1.493 do Código Civil uruguaio privilegiaram tal teoria, uma vez que foram baseados no art. 1.119 do Esboço de Teixeira de Freitas.

201. Cf. cap. IV.2.1. e Allara, op. cit. (nota I supra), p. 260. Cf., também, dentre outros, Medicus, Schuldrecht. I. Allgemeiner Teil, I1: ed, München, C.H. Beck, 1999, p. 125, Wolf, Lehrbuch des Schuldrechts. I. Allgemeiner Teil, Köln-Berlin-Bonn-München, Heymann, 1978, p. 395, Brox, Allgemeines Schuldrecht, 26a ed., München, C.H. Beck, 1999, p. 98, e Titze, Bürgerliches Recht-Recht der Schuldverhältnisse, $4^{\mathrm{a}}$ ed., Berlin, Springer, 1948, p. 86.

202. Segundö Von Thur, Allgemeiner Teil des Schweizerischen Obligationrechts, Tüibingen, J. C. B. Mohr, 1924 (trad. esp. de W. Roces, Tratado de las Obligaciones, tomo 2, Madrid, Editorial Reus, 1934, p. 12), nos casos de evicção na datio in solutum, antes do BGB, o direito comum reservava ao credor a escolha entre o renascimento da prestação primitiva ou a garantia por evicção e vícios da coisa. Coın o $\$$ 365 do BGB, como sabemos (cf. nota 200 supra), a prestação inicial é completamente extinta. O autor considera a solução adotada pelo $\$ 365$ do BGB como a mais justa, uma vez que, caso contrário (ou seja, o renascimento da obrigação primitiva), os fiadores ou prestadores de qualquer outra garantia ( $1:$., hipoteca), liberados pela datio in solutum, estariam novamente responsabilizados os casos de evicção. 
coisa, um crédito ou um direito outro é dado em pagamento, o devedor deverá prestar garantia por eviç̧ão ao credor, como se este fosse um comprador. O $\$ 365$ do BGB, como lembra Allara, ${ }^{203}$ exclui qualquer possibilidade de renascimento da prestação originária, que foi extinta definitivamente pelo aceite do credor à troca de objeto. ${ }^{204} \mathrm{O}$ legislador alemão, continua Allara, ${ }^{205}$ entendeu não ser correto o ordenamento jurídico ignorar o acordo de vontades do credor e do devedor que proporcionou a datio in solutum, devendo considerar a garantia por evicção da coisa implícita na tradição efetuada pelo devedor. ${ }^{206}$

Essa solução, que equipara o credor evicto ao comprador também evicto, é baseada na aproximação entre a datio in solutum e a compra e venda.

Espínola ${ }^{207}$ ressalta que essa fôra a posição adotada pelos códigos estrangeiros maciçamente, já que, $v$. g., os legisladores e doutrinadores italianos e franceses ${ }^{201}$ afastaram a hipótese de renascimento da prestação primitiva ao adotarem a tese da novação para a natureza jurídica da datio in solutum.

Mais importante que as legislações citadas que consagram essa posição é a explicação de Espínola, ${ }^{2(1)}$. que corrobora tal posição, justificando a equiparação do

203. Op. cit. (notu I supra), p. 260.

204. Vale lembrar a observação de Larenz, op. cit. (notı 78 supra), p. 418 ; sobre a adoção de tal teoria pelo $\$ 365$ do BGB. Segundo o autor, como vimos, ao equiparar o credor evicto da dação em pagamento ao comprador, não podemos reviver a prestação primitiva, o $\$ 365$ do BGB tornou-se incompatível com a posição dos doutrinadores que defendem a datio in solutum possuir a natureza jurídica de modalidade de pagamento. Entretanto, tal teoria é contestada por Allara, op. cit. (nota I supra), p. 50, para quem, a adoção desta teoria contradiz o $\$ 364$ do BGB, que considera a datio in solutum um contrato real (Realvertrag).

205. Op. cit. (nota I supra), p. 260.

206. Allara, op. cit. (notu I supr(u), p. 260 , ainda, critica a posição adotada pelo BGB, uma vez que o seu $\$ 365$ considerou extinta a relação obrigacional, mesmo quando não seja efetuada a prestação determinada pelas partes como equivalente ao adimplemento. Segundo o autor, tal solução não encontraria apoio no direito positivo italiano.

207. Op. cit. (nota I supra), pp. 75-77. Espínola lembra também (op). cit. (nota I supra), pp. 74-75, n. 135) que tal posição, que iguala o credor evicto ao comprador, também foi privilegiada pelo Esboço de Teixeira de Freitas, em seu art. 1.119, e pelo Anteprojeto do Código de Obrigações, em seu art. 303.

208. Cabe ressaltar que Pontes de Miranda, op. cit. (nota I supra), p. 12, contudo, critica essa posição, considerando uma falta de técnica dos códigos italiano e francês utilizar analogicamente as normas da compra e venda sobre vícios redibitórios e sobre eviç̧ão para os casos de datio in solutum. Para o autor, a solução brasileira contida no Código Civil é muito superior, ao trazer no art. 998 a regra sobre o credor evicto na dação em pagamento e nos arts. 1.101-1.106 sobre os vícios redibitórios, que se aplicam a todos os contratos onerosos e comutativos. Assim, a solução do Código Civil brasileiro prescinde da interpretação analógica com a compra e venda, para os vícios redibitórios e a eviç̧ão da datio in solutum.

209. Op. cit. (nota / supra), pp. 76-77. 
credor evicto ao comprador que se encontra na mesma situação. Desse modo, segundo aquele autor, primeiramente, deve-se distinguir quando a datio in solutum é nula e quando há casos de evicção ou vícios redibitórios. No primeiro caso, da nulidade da dação em pagamento, a obrigação original não foi extinta, uma vez que não há efeito extintivo resultante de uma dação nula. Já no segundo caso, relativos à evicção e aos vícios redibitórios, se a dação em pagamento se efetuou de modo válido, a obrigação primitiva extinguiu-se. Por conseguinte, segundo o mesmo autor, como a obrigação foi extinta, não se deve restabelecer, devendo, portanto, o credor, contar com as garantias mesmas do comprador.

Desse modo, tal garantia do credor levará ao seu ressarcimento. Cabe questionar se tal ressarcimento será respectivo à prestação original ou à nova prestação estabelecida pela dação em pagamento. ${ }^{210}$ Segundo Zaccaria, ${ }^{211}$ não há dúvidas que tanto no ordenamento italiano quanto no alemão, o ressarcimento deverá ser relativo à nova prestação. Assim, o credor deverá ser indenizado com base no objeto da datio in. solutum que substituiu a prestação originária.

\subsection{Escolha a critério do credor evicto}

Em face da controvérsia entre as duas posições relativas aos casos de evicção da datio in solutum, temos a possibilidade, defendida por alguns, ${ }^{2 / 2}$ do credor escolher entre a retomada da prestação original e a prestação de garantia por evicção pelo devedor.

Essa foi a solução adotada pelo Código Civil italiano, de 1942, que em seu art. 1.197, II e III, conferiu ao credor evicto a possibilidade de escolher entre o renascimento da prestação original, incluindo as perdas e danos e a garantia por eviç̧ão, equiparado ao comprador. Cabe ressaltar que o renascimento da prestação primitiva, prevista pelo Código Italiano, não implica no renascimento das garantias prestadas por terceiro. ${ }^{213}$

210. Cf. Zaccaria, op. cit. (note l supra), pp. 254-255.

211. Op. cit. (nota I supra), p. 255.

212. Trata-se da mesma solução encontrada por alguns autores quanto aos textos de Marciano e Ulpiano (cf. cap. IV.1, quintu solução, e nota 157).

213. Cf. Antunes Varela, op. cit. (nota I supra), p. 205 e; Grassetti, Datio in solutum in NNDI cit. (nota 61 supra), p. 175. Grassetti acrescenta que esta era uma questão controversa no Código Civil italiano de 1865 que, como sabemos, não previa expressamente o instituto da datio in solutum. Essa indefinição pode ser percebida no artigo do próprio autor no Nuovo) Digesto Italiano) (Datio in solutum cit. (notu 26 supr(t), p. 550), anterior ao Código Civil, de 1942. Segundo o autor, entretanto, a atual solução é semelhante a que poderia ser inferida do antigo Código. 
Saleilles ${ }^{214}$ observa que os romanistas alemães anteriores ${ }^{21.5}$ ao BGB apoiavam essa possibilidade de escolha do credor, pois tentavam conciliar os textos de Marciano e Ulpiano. Os autores justificavam tal posição, considerando que o direito de fazer renascer a obrigação primitiva era referente ao credor ter considerado a transferência da propriedade da coisa dada como se fosse um adimplemento, e que o direito da garantia por evicção decorria da obrigação implícita de transferir a propriedade da coisa mediante a traditio, obrigação esta assumida pelo devedor. ${ }^{216}$ Vale lembrar, que como vimos, o $\$ 365$ do BGB excluiu esta possibilidade escolha, considerando a datio in solutum definitiva e aplicando as garantias da compra e venda para a evicção.

Essa solução é bastante criticada, pois considera-se juridicamente impossível uma concorrência alternativa entre as duas ações. Segundo Allara, ${ }^{217}$ não se pode aceitar que uma mesma relação obrigacional exista e inexista ao mesmo tempo, como ocorre em tal solução. Assim, não se pode cogitar em uma escolha do credor, ora revivendo uma obrigação, ora considerando-a definitivamente extinta.

\subsection{Outras soluções}

Restam ainda duas outras soluções para os casos de credor evicto, a da cumulação de ambas as ações e a da distinção entre a ação reivindicatória e a hipotecária. São originárias de diferentes interpretações dos textos de Marciano e Ulpiano, não tendo grande repercussão no Direito moderno.

Desse modo, a primeira solução concede ao credor evicto o cúmulo das duas ações, a de renascimento da prestação primitiva e a de garantia como um comprador, até o ressarcimento completo do prejuízo proveniente da evicção. ${ }^{218}$ Como já examinamos, ${ }^{219}$ é a solução defendida por Glück, ${ }^{220}$ dentre outros.

Allara ${ }^{221}$ explica que o credor que sofre evicção pode cumular as

214. Thécorie générale de l'obligation, $3^{\mathrm{a}}$ ed., Paris, LGDJ, 1925, p. 39. Cf., no mesmo sentido, Carvalho de Mendonça, op. cit. (nota I supra), p. 586.

215. Cf., dentre outros, Arndts, op. cit. (nota 42 supra), p. 358.

216. Cf. nota 202 supra.

217. Op. cit. (nota I supra), p. 262.

218. Cf. nota 157 supra.

219. Cf. cap. IV.1., sexta solução.

220. Op. cit. (nota 159 supra), p. 149.

221. Op. cit. (nota / supra), p. 161. 
vantagens das duas ações, sem a necessidade de concorrência. ${ }^{222}$ Entretanto, o mesmo autor considera tal cúmulo de ações juridicamente impossível, uma vez que ter-se-ia o absurdo da ação de garantia por evicção não ter como seu objeto a coisa evicta ou o seu valor, já que este seria ressarcido pela ação do crédito originário.

A outra solução é a consagrada, dentre outros, por Giorgi ${ }^{22.3}$, prevendo o renascimento da prestação primitiva para os casos de ação reivindicatória e a garantia por evicção na ação hipotecária. ${ }^{224}$ Também Alves Moreira ${ }^{225}$ faz tal distinção, considerando, nos primeiros casos, anulada a transferência de propriedade e, nos casos de execução hipotecária, que o credor ficará sem a coisa ou, caso prefira a expurgação da hipoteca, sem o "preço"226. (o crédito, no todo ou em parte). ${ }^{227}$

\section{Extinção das garantias}

Com a retomada da prestação primitiva, prevista no art. 998 do Código Civil brasileiro, para os casos de credor evicto na datio in solutum, importante questão levanta-se a respeito das garantias: renasceriam também, juntamente com o crédito, todas as garantias a acessórios do mesmo? Tal dúvida não se apresenta no direito estrangeiro, já que, como vimos, não se fala em restabelecimento da prestação original. ${ }^{228}$

Em relação à fiança, o art. 1.503, III, do Código Civil brasileiro, é expresso

222. Allara, op. cit. (notı / supra), p. 261, traz uın exemplo de aplicação desta solução: "Da questa formulazione se l'ammontare del credito originario è di 100 e il pregiudizio patrimoniale complessivo dell'evizione è di 150, il creditore potrà pretendere, oltre alla prestazione primitiva, una indennità di 50."

223. Op. cit. (nota 29 supra), pp. $391-392$.

224. Cf. cap. IV.I., sétima soluçāoo.

225. Op. cit. (nota 43 supra), p. 279.

226. Alves Moreira, op. cit. (nota 43 supra), p. 279, utiliza o termo preço, uma vez que, como já dissemos (cf. cap. III.2.1), o autor considera que a natureza jurídica da dação em pagamento é a compra e venda.

227. Segundo Allara, op. cit. (nota / supra), pp. 262-263, tal distinção não tem fundamento, uma vez que tanto nos casos de datio in solutum de coisa alheia como nos casos de datio in solutum de coisa gravada por vínculo hipotecário não temos a satisfação do crédito e, conseqüienteınente, a não extinção do inesino.

228. O art. 1.197 do Código Civil italiano, que possibilita ao credor escolher entre a retomada da prestação primitiva a garantia por eviç̧ão (cf. cap. IV.2.3 e nota 213 supra), é claro ao afastar o renascimento das garantias prestadas por terceiros: "In ogni caso non rivivono le garantizie prestate dai terzi" (art. 1.197, III). Zaccaria, op. cit. (nota / supra), pp. 279-280, faz interessante observação quanto à utilização do verbo "rivivere" Segundo o autor, este termo não é o ideal, uma vez que se pode entender que as garantias possam extinguir-se antes da relação obrigacional. Ainda conforıne Zaccaria, isso não ocorre na grande maioria dos tasos, nāo sendo possível, assim, que as garantias "rivivono". O mesıno autor explica que o art. 1.929 do Código Civil italiano, de 1865, o antecedente imediato do art. 1.197 do Código, de 
ao liberar o fiador, ou seja, não se revigora a fiança juntamente com a prestação original. Assim, a evicção na datio in solutum é um modo de exonerar a responsabilidade do fiador: "se o credor, em pagamento de dívida, aceitar amigavelmente do devedor objeto diverso do que este era obrigado a lhe dar, ainda que depois venha a perdê-lo por evicção"

Desta maneira, abrindo esta exceção a respeito da fiança nos casos de evicção, o legislador brasileiro equiparou-se às legislações estrangeiras. ${ }^{229}$ A liberação do fiador é baseada na eqüidade. Afinal, ele não pode ser prejudicado com este acordo posterior entre o devedor principal e o credor, uma vez que não garantiu tal risco, não previsto no contrato originário. ${ }^{230}$ Pothier $^{231}$ é o precursor desta teoria, mesmo

1942, ocasionava divergências na doutrina. O artigo supracitado dispunha que se o credor aceitava voluntariamente receber coisa diversa do débito principal, mesmo sofrendo evicção, o fiador estava liberado. A controvérsia era a respeito da hipoteca. Assim, alguns autores defendiam que a hipoteca renasceria quando a evicção fosse provocada por um terceiro, mas permanecia extinta caso a evicção decorresse de ação hipotecária promovida por credores que garantiam o imóvel dado em pagamento. Baseavam-se nos arts. I.240 e 2.03 | do Código Civil italiano, de 1865 , que determinavam ser inválido o pagamento que tem como objeto uma transferência de propriedade, caso não fosse feito pelo proprietário da coisa ou alguém capaz de aliená-la e que a hipoteca seria restabelecida com o crédito cujo pagamento fosse nulo, respectivamente. Já outros autores entendiam que o crédito originário renascia eın todas as hipóteses juntamente com a hipoteca, devendo considerar o fiador como uma exceção determinada pelo art. 1.929 do Código Civil, de I865. Desse modo, o art. 1.197 do Código Civil italiano, de 1942 resolveu tal questão, considerando extintas quaisquer garantias da prestação original, sejam elas reais ou pessoais. O art. 2.038 do Código Civil francês e o $\$ 365$ do BGB não admitem o restabelecimento da prestação inicial para os casos de credor evicto, não apresentando tal problema. Mourlon-Demangeat, Répétitions écrites sur le code civil, tomo 3, Paris, Garnier Frères, 1892, pp. 543-544, ao explicar o art. 2.038 do Código Civil francês, entende que a dação em pagamento só extingue a obrigação primitiva com a transferência de propriedade da coisa. Caso esta não ocorra, o devedor continua obrigado, devendo, a priori, serem mantidas as garantias. Entretanto, em favor do terceiro prestador de garantia, entende-se que as garantias permanecem extintas.

229. No ordenamento italiano, segundo De Ruggiero, Istituzioni di Diritto Civile, v. 2, 4a ed., Messina, Giuseppe Principato, 1926, pp. 99-100, a datio in solutum "ha virtù di estinguere il credito e di liberare $\mathrm{i}$ fideiussori anche quando il creditor venga in seguito a soffrir l'evizione della cosa" (cf., no mesmo sentido, Lomonaco, Delle obbligazioni e de contrati in genere, v. 2, $2^{\mathrm{a}}$ ed., Torino, UTET, 1925, p. 51, n. i). Do mesmo ınodo, o Código Civil francês e alemão (cf. nota 228 supra). Carvalho de Mendonça, op). cit. (notı I supra), p. 588 e Pontes de Miranda, op. cit. (nota I supra), p. 22, afirmam que o Código Civil brasileiro adotou posição contrária ao BGB quanto à liberação do fiador, já que no direito alemão, nos casos de retomada da prestação primitiva, todas as garantias subsistem. Na verdade, não existe tal divergência, já que o direito alemão não se refere aos casos de eviç̧ão, conforme indicam tais autores, mas sim aos casos de anulação da datio in solutum, como afirma Dernburg, Das bïrgerliche Recht des Deutschen Reichs und Preukens, v. 2, t. 1, 4" ed., Halle, Waisenhauses, 1909, p. 326: "War die Leistung na Erfüllungsstatt nichtig - so bleibt selbstverständlich die Forderung als nur scheinbar getilgt bestehen und die Befreiung der Bürgen wie anderer Akzessionen ist nich erfolgt"

230. Cf. Carvalho de Mendonça, op. cit. (nota I supra), p. 588, e Cunha Gonçalves, Tratado de Direito Civil, v. 5, tomo 1, 2ª ed., São Paulo, Max Limonad, 1955, p. 262. Cf., também, nota 202 supra.

23I. Oeuves de Pothier - annotées par M. Bugnet, v. III, $3^{\text {a }}$ ed., Paris, Marchal et Billard, 1890, p|). 240-24l. 
defendendo a subsistência da antiga prestação com todos os seus acessórios na datio in solutum, ${ }^{232}$ considerando uma injustiça esse aumento de responsabilidade do fiador.

Quanto às outras garantias, cabe-se analisar, principalmente, a hipoteca prestada por terceiros. A doutrina brasileira dominante ${ }^{2.33}$ defende o seu renascimento, juntamente com a prestação original. Segundo tais autores, a hipoteca é tratada especialmente pelo art. 849, I, do Código Civil brasileiro que, combinado ao art. 998, garante a sua retomada. Além disso, segundo Carvalho de Mendonça, ${ }^{2.34}$ não tem animurs solvendi o devedor que efetua dação em pagamento com bens gravados de hipoteca. ${ }^{235}$

Por outro lado, João Luís Alves ${ }^{236}$ entende que a exceção feita para a fiança deve ser estendida à hipoteca, liberando, assim, o terceiro prestador da garantia. O autor apoia a sua posição na doutrina francesa ${ }^{237}$ que, ao analisar o art. 2.038 do Código Civil francês (artigo este em que foi baseado o art. 1.503, III, do Código Civil brasileiro), amplia, analogamente, a extinção da fíança à hipoteca e ao penhor. ${ }^{2.3 x}$

Por último, resta citar a questão levantada por Antunes Varela: ${ }^{231)}$ Teria o credor que agisse de má-fé24) tais garantias? Ou seriam privilegiados os terceiros,

232. Pothier, op. cit. (notı 231 suprat), pp. 238-239, não segue a doutrina francesa dominante, criticando a tese da novação. Assim, segundo o autor, não há umna obrigação nova que extingue a antiga (cf. também Giffard, Droit Romain et Ancien Droit Franģais - Les obligations, 3ª ed., Paris, Dalloz, 1970, p. 318).

233. Cf. Pontes de Miranda, op. cit. (nota I supra), p. 22, Carvalho de Mendonça, op). cit. (nofa I supra), p. 588, Antunes Varela, op. cit. (nota / supra), p. 205, Serpa Lopes, op. cit. (nota /2 suprat), pp. 252-253, e Carvalho Santos, op. cit. (nota 12 supra), p. 218.

234. Op. cit. (nota / supra), p. 588.

235. Serpa Lopes, op. cit. (nota 12 supra), p. 25.3, acrescenta que o renascimento da hipoteca prestada por terceiros tem restrição, principalmente devido a sua condição de eficácia real, que necessita da inscriç̧̃o no registro imobiliário. Desta maneira, segundo o mesmo autor, o restabelecimento só pode ocorrer contra o terceiro prestador da garantia real, não podendo atingir un terceiro possuidor que tiver transcrito o seu título.

236. Código Civil da República dos Estudos Unidos do Brasil - anotado, v. 4, 3. a ed., Rio de Janeiro, Borsoi, 1958, p. 109.

237. Cf. Huc, op. cit. (notu 68 supra), pp. 48-49.

238. Serpa Lopes, ojp. cit. (notu 12 supra), p. 253 , entretanto, defende que não se trata de um calso idêntico no direito brasileiro, não havendo elementos para uma aplicação analógica da legislação da fiança.

239. Op. cit. (nota I supra), p. 206.

240. Antunes Varela, op. cit. (nota I supra), p. 206, exemplifica tal situação, com o credor que "forçou ilicitamente o devedor a entregar-Ihe, em pagamento da dívida, coisa não pertencente ao autor (a entrega ou que o credor sabia (e o devedor ignoravil) que a coisa entregue em pagamento pertencia a terceiro". 
prestadores primitivos das garantias, já que seriam exonerados com a extinção da obrigação? O autor enfienta a questão sem resolvê-la, afirmando que a sua solução não é apresentada pelo direito vigente, não apresentando disposição expressa, nem qualquer caso análogo. ${ }^{24 !}$

\section{$V$ Conclusão}

Preliminarmente, cabe ressaltar, a relevância das soluções do Direito Romano para o direito civil moderno. As controvérsias presentes nas fontes, quanto à dação em pagamento, são as mesmas que permeiam as posições opostas adotadas pelos ordenamentos atuais. Especialmente para o direito brasileiro, que privilegiou a solução afastada pelos outros códigos. Desta maneira, é fundamental a realização de um estudo de neo-pandectística, mesmo em um trabalho exclusivamente de direito contemporâneo, ao se tratar da datio in solutum ou de outras figuras jurídicas que resguardam profundas relações com fontes romanas. Cuidando, obviamente, da diversidade histórica e cronológica, o Direito Romano pode ser visto como uma grande fonte de direito comparado.

Já quanto à natureza jurídica da figura, como já dissemos, preferimos a solução adotada pelos juristas mais contemporâneos, salientando os fundamentos basilares da fïgura. Entretanto, não se pode afastar a importância de tal discussão para a análise dos casos de evicção na datio in solutum, tema central de nosso estudo.

Por conseguinte, segundo nosso entendimento, a melhor solução para os casos de credor evicto na dação em pagamento é a da garantia por eviç̧ão análoga ao do comprador, estendendo a aplicação das normas do contrato de compra e venda. Esse tratamento é o que melhor atende aos interesses das partes e do sistema jurídico.

Afinal, deve-se privilegiar o acordo de vontades entre o credor e o devedor que efetuaram a dação em pagamento, mantendo a mudança da prestação. ${ }^{242}$ Além disso, preserva as características da própria figura, ou seja, a substituição da prestação inicialmente devida, uma vez que a garantia por eviç̧ão remete à nova prestação. ${ }^{243}$

241. Segundo o mesıno autor, "as hipóteses previstas no art. 979 (autorização do credor para o levantamento do depósito judicial, depois de o ter aceitado ou de ter contestado a lide) e no art. 1.108 (exclusão da garantia da eviç̧ão, quando o adquirente a tenha excluído, sabendo do risco dela, ou tenha assumido esse risco) não têm, de fato, inteira analogia com o caso da dação eın pagamento"

242. Cf. Allara, op. cit. (notcl / supra), p. 260.

243. Cf. Zaccaria, op. cit. (notu / supra), pp. 254-255. Diferentemente do restabelecimento da prestação primitiva, a garantia por evicção análoga à compra e venda prevê o ressarcimento do credor com base na nova prestação. 
Ademais, esse posicionamento elimina o problema das garantias prestadas por terceiros, já que a prestação original está defïnitivamente extinta. Assim, é inútil a discussão da doutrina pátria ${ }^{244}$ sobre quais garantias e acessórios deveriam ser restabelecidos. A nosso ver, não tem sentido responsabilizar terceiro que já havia sido liberado com a datio in solutum. ${ }^{24.5}$

Contudo, o principal argumento que corrobora a adoção desse tratamento para tais casos é a complexão do ressarcimento do credor. Este, notoriamente a parte prejudicada, já que sofreu a evicção, deve ter facilitada a sua indenização. Desse modo, a garantia por evicção proporcionará ao credor a completa satisfação do seu prejuízo, já que tal ação permite reparar todos os danos. ${ }^{24(6}$

Vale lembrar, ainda, que as outras soluções apresentadas mostram-se bastante inadequadas para a matéria.

Desta maneira, o restabelecimento da prestação primitiva, adotado pelo art. 998 do Código Civil brasileiro, falha no tocante à indenização do credor. Afinal, o mero renascimento do crédito original não-remete aos eventuais outros prejuízos do credor: ${ }^{247}$ Além disso, tem-se a questão relativa às garantias por terceiros, já explicada anteriormente. ${ }^{24 x}$

Já o tratamento que prevê a possibilidade de escolha do credor entre o renascimento da prestação primitiva e a garantia por evicção, ${ }^{24 '}$ segundo nossa opinião, apresenta fallhas técnicas. Não é possível considerar que uma única obrigação esteja extinta e não-extinta ao mesmo tempo. ${ }^{250}$

244. Cl. Pontes de Miranda, op). cit. (nota I supral), p. 22, Carvalho de Mendonça, op. cit. (nota I suprat), p. 588, Antunes Varela, op. cit. (nota I supra), p. 205, Serpa Lopes, op. cit. (nota /2 supra), pp. 252 253, Carvalho Santos, op. cit. (nota 12 suprol), p. 218 , e João Luiz Alves, op. cit. (nota 236 supra), p. 109.

24.5. Acompanhamos a opinião de Von Thur, op). cit. (nota 202 supral), p. 12.

246. Nardi, op. cit. (notu 13 supra), p. 120, é bastante claro em considerar a garantia por evicção a melhor solução para os casos de credor evicto: "Ne deriva che il mutare l'azione dalla vendita (actio utilis ex empto) offre al creditore possibilità di risarcimento più ampio e sostanzioso - alıneno nei casi in cui se ne dia la necessità - di quello connesso con la semplice azione dí credito"

247. Allara, op. cit. (nota I supra), p. 259, e Zaccaria, op. cit. (nota I supra), p. 26I, acrescentam que o credor evicto, nesses casos, terá de inover outra ação para ser ressarcido, tendo o ônus da prova da culpa in contrahendo do devedor e sendo a indenização limitada ao valor do seu interesse negativo. Ou seja, privilegiar essa teoria leva e um aumento desnecessário de ações, todas elas contidas na garantia por evicção.

248. CF. cap. IV.3.

249. Consagrada pelo art. 1.197, Il e III do Código Civil italiano.

250. Allara, op. cit. (nota I supra), p. 262. 
Do mesmo modo, as demais soluções propostas pela doutrina não são adequadas ao melhor tratamento do tema. A cumulação de ambas as ações ${ }^{251}$ até o completo ressarcimento do credor esbarra no mesmo problema teórico do art. I.197, II e III do Código Civil italiano. Já a distinção entre os casos de ação reivindicatória e os de ação hipotecária, ${ }^{252}$ a nosso ver, não encontra qualquer justificativa coerente.

Portanto, como sugestão de lege ferenda, propomos a revogação do art. 998, do Código Civil brasileiro. A sua supressão, simplesmente, alteraria o tratamento dos casos de evicção, passando do restabelecimento da prestação original para a garantia por evicção, devido a equiparação às normas da compra e venda feita pelo art. 996, do Código Civil. Na verdade, tal equiparação nem precisaria ser prevista, uma vez que nosso Código prevê entre as normas dos contratos onerosos em geral, ${ }^{2.53}$ como a dação em pagamento, as relativas à eviç̧ão.

São Paulo, janeiro de 2001.

251. Proposta por Glïck, op. cit. (nota 159 supra), p. 149. Cf. cap. V.2.4.

252. Cf. Giorgi, op. cit. (nota 29 supra), pp. 39 1-392, e Alves Moreira, op. cit. (nota 43 supra), p. 279.

253. Como bem ressalta Pontes de Miranda, op. cit. (nota I supra), p. 12. 